\title{
Sticky business - Why do beekeepers keep bees and what makes them
} successful in Tanzania?

Wagner, Kata; Meilby, Henrik; Cross, Paul

\section{Journal of Rural Studies}

DOI:

10.1016/j.jrurstud.2019.01.022

Published: 01/02/2019

Peer reviewed version

Cyswllt i'r cyhoeddiad / Link to publication

Dyfyniad o'r fersiwn a gyhoeddwyd / Citation for published version (APA):

Wagner, K., Meilby, H., \& Cross, P. (2019). Sticky business - Why do beekeepers keep bees and what makes them successful in Tanzania? Journal of Rural Studies, 66, 52-66.

https://doi.org/10.1016/j.jrurstud.2019.01.022

\footnotetext{
Hawliau Cyffredinol / General rights

Copyright and moral rights for the publications made accessible in the public portal are retained by the authors and/or other copyright owners and it is a condition of accessing publications that users recognise and abide by the legal requirements associated with these rights.

- Users may download and print one copy of any publication from the public portal for the purpose of private study or research.

- You may not further distribute the material or use it for any profit-making activity or commercial gain

- You may freely distribute the URL identifying the publication in the public portal ?
}

Take down policy

If you believe that this document breaches copyright please contact us providing details, and we will remove access to the work immediately and investigate your claim. 


\title{
Sticky business - why do beekeepers keep bees and what makes them successful in Tanzania?
}

\begin{abstract}
The estimated economic potential for the apiculture sector in Africa is currently unmet, and in part due to a lack of training in appropriate beekeeping techniques. Development agencies promote beekeeping widely in developing nations to alleviate rural poverty and simultaneously provide an incentive for forest conservation. There is little robust evidence to suggest that beekeeping interventions target the most suitable beneficiaries, or that training length and content are adequate to sustainably promote beekeeping in sub-Saharan Africa. This study aimed to determine predictors of both beekeeping adoption and levels of dependence on beekeeping. We also assessed whether the type and quantity of external assistance appeared to influence beekeeping success. We applied a mixed methods approach to identify beekeeper characteristics and identify key drivers and barriers to beekeeping in four communities in central Tanzania. Income and food provision were the main drivers for beekeeping adoption, but the effects of these were moderated by both the respondents' cultural background, and the perceived human health risks posed by African bees. Land ownership, technical knowledge, initial capital inputs and hive theft were important constraints to adopting beekeeping. We found that formal beekeeping training did not result in increased yields and propose that training provided by the majority of development agencies is inadequate to address the technical capacity requirements of local beekeepers. We also propose that the requirement to form associations to access project benefits creates divisions in communities and needs to be handled with more care than is currently done.
\end{abstract}

Keywords: Apis mellifera, honey, livelihood diversification, rural development, non-timber forest products, alternative livelihood projects

\section{Highlights}

1. We identified the predictors of beekeeping adoption, dependence and success in central Tanzania.

2. Farmers mostly adopt beekeeping for the income benefits from bee products.

3. Theft of hives and lack of land, capital and knowledge are major constraints for adoption.

4. Beekeeping training by the government organizations does not lead to increased yields.

5. Project delivery through beekeeping associations may cause conflict and inefficiencies. 


\section{Introduction}

The elimination of extreme poverty and the reversal of forest degradation are prominent international development objectives (UN General Assembly resolution 70/1, 2015). Given the scale of interdependencies between poverty and forest loss, many governments and development agencies seek to address the two issues conjointly (UNDP, 2013, 2015; USAID, 2014, 2015; World Bank, 2013). Current conservation approaches aim to incentivize local communities by linking economic development and livelihoods with the protection of natural resources (Brandon and Wells, 1992; Roe et al., 2014; Salafsky and Wollenberg, 2000).

Alternative livelihood projects are a prominent example of linked development and conservation strategies (APFIC, 2010; Roe et al., 2014; USAID, 2016). These approaches can link livelihoods and conservation indirectly by substituting local communities' reliance on natural resources with alternatives, e.g. reducing dependence on bushmeat by introducing domesticated sources of meat. Or they can give local communities an immediate stake in the preservation of natural resources by directly benefitting from biodiversity through biodiversity-based livelihood activities using nontimber forest products for example. The underlying idea is that income and subsistence derived from biodiversity provide an incentive to the community to protect and conserve natural resources. (Brandon and Wells, 1992; Roe et al., 2014; Salafsky and Wollenberg, 2000). Beekeeping has been widely promoted as a successful example of an alternative livelihood project, with beekeeping products being important non-timber forest products due to their considerable commercial potential (Brown, 2001; FAO, 2011; ICIPE, 2013). Beekeeping is considered a suitable development activity by many governments and development agencies owing to relatively low initial economic investment, limited equipment and training needs, as well as minimal land requirements. The potential to generate additional income, whilst contributing to food security and delivering medicinal benefits to the rural poor, is thought to increase local resilience leading to incentives to conserve forest and tree resources (Bradbear et al., 2002; Drescher and Crane, 1982; FAO, 2011).

The Miombo woodland ecoregion extends over several countries in Southeast Africa and sustains extensive beekeeping and honey-hunting activities. (Campbell, 1996; Campbell, 2007; MickelsKokwe, 2006). Tanzania is the second largest honey-producer in Africa by volume (USAID, 2012), harvesting an estimated 30905 metric tons annually (FAO, 2017). Increased globalization and the opening of niche markets for organic and Fair Trade forest products has increased the potential for the expansion of the apiculture sector (Campbell, 2007; Shackleton, 2007). Improved in-country communication technology has facilitated linkages between rural entrepreneurs and urbancentered markets (Aker and Mbiti, 2010). This has the potential to connect beekeepers often living in remote locations with networks that could allow them to obtain cash income from their beekeeping products.

Despite these positive contributory factors, several authors have suggested that beehive product potential remains untapped across much of Southeast Africa (Carroll and Kinsella, 2013; Kihwele, 1985; Mickels-Kokwe, 2006). While a potential yield gap in African beekeeping products has recently been contested (Bradbear, 2018), the Tanzanian Government and Non-Governmental Organizations (NGOs) have developed a series of policy and technical training initiatives to improve production efficiency and gross production in the national beekeeping sector (Hausser and Mpuya, 2004; MNRT, 2016; United Republic of Tanzania, 2002). The majority of beekeeping interventions in sub-Saharan Africa comprise an admix of training, hive donation and occasionally protective equipment provision (Affognon et al., 2015; Anand and Sisay, 2011; Carroll et al., 2017; Hausser 
and Mpuya, 2004). Several support organizations encourage the modernization of beekeeping through the distribution of frame hives (Carroll et al., 2017), which are thought to be less suitable for both the local honeybee sub-species and prevailing climatic conditions (Bradbear, 2009; Carroll and Kinsella, 2013). Beekeeping promoters aim to encourage existing beekeepers to intensify and modernize their honey production, whilst also incentivizing non-beekeepers to adopt beekeeping as a supplementary livelihood activity (FAO, 2014; World Vision, 2015). However, attrition of participants following the implementation of such projects is substantial (Brown, 2001; Carroll et al., 2017). Beekeeping projects tend to be delivered to groups of beekeepers rather than to individuals, in order to maximize economies of scale (Affognon et al., 2015; Anand and Sisay, 2011; Carroll et al., 2017). Project participants are frequently selected based on their relative poverty within a community, as such individuals are more likely to demonstrate greater value added (Amulen et al., 2017; SNV, 2016). Carroll et al. (2017), found that training provision within beekeeping projects often did not reflect the complex and practical skill-set required to manage Langstroth hives (frame hives). Beekeeping training within projects usually lasts only a few days and is often class-room based (Amulen et al., 2017), delivering techniques considered too advanced for the training time frame and lacking appropriate follow up extension services (Carroll et al., 2017). Whilst insufficient knowledge of beekeeping techniques appears to be a critical factor in explaining the honey yield gap in East Africa (Affognon et al., 2015; Nel et al., 2000; Carroll, 2013; Carroll et al., 2017), there is a lack of robust studies measuring the actual effect of capacity building for beekeeping on skills (Amulen et al., 2017). Such information is critical to inform effective policy and technical delivery.

Alternative livelihood projects, among which beekeeping projects feature prominently, remain pervasive conservation and development tools in the tropics despite criticism of their effectiveness (Roe, 2008). So much so, that the International Union for the Conservation of Nature (IUCN) recently called for a critical review of alternative livelihood projects as evidence of their effectiveness has not grown at the same rate as their prominence (IUCN 2012). A subsequent systematic review, concluded, that we do not understand why most of alternative livelihood projects fail to achieve their goals (Roe et.al, 2015). This knowledge gap becomes all the more significant as efforts towards reducing emissions from deforestation and forest degradation (REDD) once again bring conservation and development agendas to converge by making alternative livelihood activities such as beekeeping fundable under the UNFCC REDD+ framework (Roe 2008, Blom et. al., 2010, UN-REDD 2012, United Republic of Tanzania 2013). This study is a step towards answering some of the questions regarding effectiveness of beekeeping interventions, by examining how the targeting and delivery of capacity building efforts could be improved to further beekeeping adoption and to increase yields of beekeepers.

For this, we identified the predictors, motivations and barriers of beekeeping adoption and characterized the relative dependence on beekeeping for subsistence and income generation. We characterized beekeeping adopters and non-adopters to identify any rural Tanzanian groups more likely to incorporate beekeeping into their livelihood activities. We also hypothesized that households with a higher dependence on beekeeping for subsistence, i.e. who use their harvested honey to supplement their calorific need, differed in location, social situation, history in beekeeping and livelihood strategies to those who were more dependent on beekeeping for income than subsistence. It is important to discriminate between beekeeper typologies as these divergent motivations to harvest bee products may also have implications for the motivation to participate in beekeeping support programs and for how participants may benefit from them. The study also 
123 assessed whether and what type of support and training influenced beekeeping success, defined 124 here as the quantity of honey harvested in the preceding twelve months. Since the aim of most 125 external beekeeping training is to increase production (Hausser and Mpuya, 2004; MNRT, 2016; 126 United Republic of Tanzania, 2002), we hypothesized that the more external training received, the 127 greater the honey harvest. We hope that the results of this analysis can provide guidance for future 128 alternative livelihood project planners intending to promote beekeeping in Tanzania and the wider 129 Miombo-region. We did not assess conservation or socio-economic outcomes of beekeeping 130 interventions as it was felt to be beyond the scope of this study. 


\section{Materials and methods}

\subsection{Study area and selection of sites}

Study participants were recruited from two known beekeeping zones in central Tanzania (Dodoma and Singida). Within these two predominantly arid regions, four rural communities were selected as study sites. All communities were located at similar distances to major roads, large markets and forests where beekeeping was undertaken. Study communities had similar population sizes, including the presence of at least 30 beekeepers and non-beekeepers, respectively, as well as a history of having received external beekeeping support (Appendix A). For the purpose of this study, 'beekeepers' were defined as those who kept bees at the time the study was undertaken or else were considered as 'non-beekeepers'. Participants who had previously kept bees but had given up the activity at the time the study was undertaken, were considered as 'non-beekeepers'.

\subsection{Sampling and data collection}

The study took place in the years 2015 and 2016. Both quantitative and qualitative data were collected. As a first step, separate focus group discussions were held with beekeepers, nonbeekeepers and village leaders to elicit any themes that motivated beekeeping uptake and success. Participants were purposefully selected to generate the widest possible, representative range of socio-economic characteristics within each community. Village leaders were asked to invite representatives of both sexes, younger and older generations, immigrants and established village residents as well as representatives of all livelihood activities. Two focus-group discussions were held separately in each community with beekeepers and non-beekeepers. Topics discussed included motivation for or against beekeeping; perceived benefits of beekeeping; perceived changes over the past decade in forest and beekeeping resources; as well as any potential conflicts between community members in the context of beekeeping and other livelihood activities. Including nonbeekeepers' perspectives on beekeeping was key to understanding potential barriers to the adoption of beekeeping. The discussions were recorded, transcribed and translated from Swahili to English.

The initial focus group discussions informed the development of the household survey, which was pretested in a community not included in the study but displaying the same general characteristics of the study communities in terms of population size, climate, predominant vegetation, land uses, distances to major roads, larger markets and forests. The survey followed the format of the Multidimensional Poverty Assessment Tool (Cohen, 2009; Saisana and Saltelli, 2010). The survey was coded by using the OpenDataKit (ODK) tool (Brunette et al., 2014). A stratified random sampling approach was applied to select approximately equal numbers of beekeepers and nonbeekeepers from each village in each community (Bryman, 2015). Randomness was introduced by assigning random numbers to all households recorded in village registries and selecting a proportional number of beekeeping and non-beekeeping households from each sub-village of a village. The questionnaire elicited socio-economic as well as beekeeping related responses relating to motivation for or against beekeeping, family background in beekeeping, technical beekeeping capacities, participation in beekeeping support programs, problems experienced in beekeeping, beekeeping success measures and experiences as beekeepers. Beekeeping related questions to nonbeekeepers concerned their family history, past experiences and possible external training received in beekeeping as well as reasons for non-adoption and conditions for potential adoption. Local 
research assistants trained in questionnaire administration, key beekeeping terminology and the use of the ODK tool implemented the survey (Angelsen et al., 2011).

A total of 318 household questionnaires were completed (155 beekeepers and 163 nonbeekeepers). Forty-five participants were invited to attend semi-structured interviews to present more detailed information on motivations for or against practicing beekeeping; status of beekeeping in the community; resource constraints; beekeeping-related conflicts; experiences in beekeeping groups as well as experiences with beekeeping training. These participants were selected based on their main livelihood activities, age, gender and beekeeping background. Lastly, semi-structured interviews were held with ten beekeeping support organizations active in the study communities and in Tanzania in general. Topics discussed included reasons for promoting beekeeping, selection criteria for program/project beneficiaries as well as indicators of success.

Ethical approval of the study was obtained through the Bangor University Research Ethics Committee (Ethical approval number: CNS2015kw1). Respondents' anonymity was maintained by assigning individual identifier codes to all research participants and storing questionnaire and interview responses under these codes. Sensitive and personal data could thus not be linked to individuals.

\subsection{Data}

Our analysis explored several potential predictors suggested in the relevant literature as determinants in the adoption of new agricultural technologies in least developed countries (Rahm and Huffman, 1984; Feder and Umali, 1993; Doss and Morris, 2000; Abdulai and Huffman, 2005). We hypothesized the following indicators to have significant associations with beekeeping adoption: age and education levels (as proxies for human capital), household size (as a proxy for labor availability), forest area owned (individual de facto and/or de jure use rights over natural and planted forests), distance to forest and livestock keeping (as proxies for access to input), distance to road (as a proxy for the relative ease of physically accessing non-local honey and wax markets used by the local population), length of residence (as a proxy for social capital), honey hunting activity and parental beekeeping (proxies for cultural proximity to beekeeping activities) (Appendix B) . For the continuous variables we applied two-sample t-tests to determine if the two population means (for beekeepers and non-beekeepers) were significantly different. Further, we used Pearson's chisquared tests to determine whether the proportions for categorical variables in the beekeeping and non-beekeeping groups were equal. Finally, factors, which were found to be significantly different between the two populations, were analyzed using an ordinary binary logit model. The distribution of the residuals was used to validate the logit link function. An independence test between all variable combinations considered for the regression model was performed using standard Pearson's chi-squared test in order to exclude any moderated relationships. Model selection was based on the lowest Akaike Information Criterion (AIC) score. Model variables were tested for multicollinearity, random effects of sub-villages as well as interactions. Lastly, barriers and conditions for beekeeping uptake were analyzed using descriptive statistics. This analysis of predictors of beekeeping adoption was the only part of our study that included non-beekeepers. The analysis of predictors of levels of dependence and success in beekeeping only encompassed beekeepers' responses.

For the analysis of dependence on beekeeping for subsistence and for income we examined the same range of hypothesized predictor variables as for beekeeping adoption, as well as variables 
representing the ex-ante motivation behind beekeeping adoption and the source of beekeeping training received (Appendix D). The dependent variables for dependence on beekeeping for subsistence and income were expressed in percentage shares and were thus bounded from above and below, i.e. assuming values between $0-100$. They also showed highly asymmetric distributions towards the lower boundary ( 0 ) and a large proportion of zeros. Two-part binary and fractional regression models were used to determine predictor variables. For both dependent variables, the discrete components (determining whether values were equal to 0 or not) were modelled as binary logit models and the continuous components (determining actual levels where values were not equal to 0 ) as fractional regression models. For this percentage values were converted to fractional $(0-1)$ values. The binary model component predicts the probability of the dependent variable being non-zero. The fractional component predicts the fractional value in case the dependent variable is a non-zero.

Lastly, for beekeeping success, defined here as liters of honey harvested in the 12 months prior to our survey in 2016 (obtained through recall and encompassing two honey flow seasons), we tested the same hypothesized predictor variables as for beekeeping adoption and dependence as well as additional variables representing technical capacity and individual training history (Appendix G). While "liters harvested" is a relatively narrow definition of beekeeping success, other possible indicators such as the number of hives owned, the level of dependence on beekeeping or marketing success had their own limitations (African beekeeping is an extensive form of beekeeping, i.e. beekeepers own many hives, but not all of these are occupied all the time; level of dependence and marketing success can both also be a result of other circumstances and might not directly indicate 'success'). Liters harvested was felt to be an easily measurable proxy for how skilled a beekeeper was in beekeeping terms only. External factors such as droughts, fires or pests were not considered for the model as these factors would have had an impact on all local beekeepers and would not have explained any difference in liters harvested over a given time period. Since harvest quantities showed a skewed distribution with a high proportion of zeros we applied a two-part binary and fractional regression modelling approach here as well. For this, we divided the number of liters harvested by the maximum number of liters reported (600 liters) in order to get values between 0 1.

Variables tested as predictors for beekeeping adoption, dependence on beekeeping for subsistence and income as well as beekeeping success were selected based on previously assessed significant relationships or correlations (Appendix I) or because they were theoretically hypothesized to have relationships with the respective dependent variables, i.e. beekeeping adoption, beekeeping dependence for subsistence, beekeeping dependence for income and beekeeping success. Problems beekeepers experienced, aspects training was received on, source of training as well as existing and desired beekeeping skills were also analyzed using descriptive statistics. Interview and focus group transcripts were coded both deductively and inductively according to the main research questions and extracting additional themes as they occurred (Ritchie et al., 2013). The aim of the coding was to capture and interpret common sense, substantive meanings in the data. During the coding of the transcripts the coding framework was continuously revised to incorporate emerging themes. The focus of this paper is on the analysis of quantitative data and the results of the qualitative analysis are used here to annotate the result and discussion sections. 


\section{Results}

\subsection{Determinants of beekeeping adoption}

Beekeepers $(\mathrm{n}=155)$ cited income from honey (89\%), provision of food $(74 \%)$ and income from wax $(64 \%)$ as the main reasons for keeping bees (Figure 1a). Non-beekeepers $(n=163)$ identified a lack of capital (54\%), knowledge (37\%) and space (26\%) as the three most important reasons for not adopting beekeeping (Figure 1c). Respondents who had previously practiced beekeeping, but subsequently abandoned this activity $(n=39)$ indicated that theft of hives/honey $(54 \%)$ and lack of space and capital (both 9\%) were the primary causes of activity cessation (Figure 1b). The most frequently cited reasons for not adopting beekeeping by non-beekeeping respondents whose parents used to keep bees $(n=78)$, were lack of access to necessary resources $(43 \%)$, fear of bees $(18 \%)$ and theft of hives/honey (15\%) (Figure 1d). The most frequently indicated conditions for beekeeping uptake among non-beekeepers were access to capital (64\%), to land/space for beekeeping (38\%) and provision of training and advisory support in beekeeping techniques (both $31 \%)$.
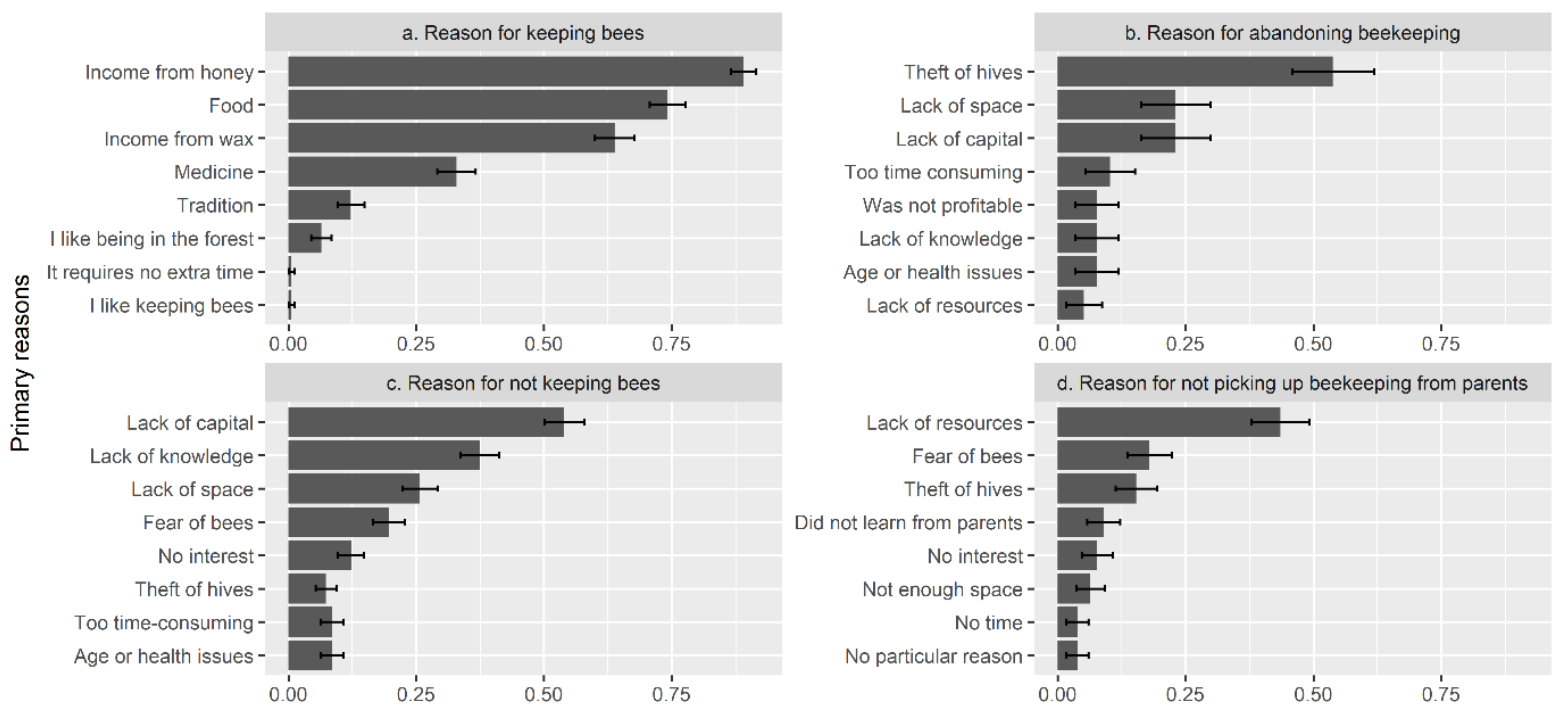

Proportion of responses

Figure 1. - Proportion of reported primary reasons for (a) and against (c) beekeeping adoption, for abandoning beekeeping (b) and for not picking up beekeeping from parents (d).

In statistical tests, beekeepers came from a background of considerably higher forest ownership, percentage of honey hunters, parental beekeeping and livestock keeping than non-beekeepers (Table 1, Appendix B). 
Table 1. - Continuous (t-test) and binary (chi-squared test) predictors of beekeeping adoption (sample size: 155 beekeepers, 163 non-beekeepers) (see Appendix B for all tested variables).

\begin{tabular}{lccc}
\hline Continuous predictors & $\begin{array}{c}\text { Beekeepers } \\
\text { mean }( \pm \text { SE) }\end{array}$ & $\begin{array}{c}\text { Non-beekeepers mean } \\
( \pm \text { SE) }\end{array}$ & t value \\
\hline HH size (Adult equivalent $\left.{ }^{1}\right)$ & $2.79( \pm 0.1)$ & $2.50( \pm 0.1)$ & $-2.35^{*}$ \\
Age (years) & $49.03( \pm 1.2)$ & $50.56( \pm 1.2)$ & 0.90 \\
Forested area owned ${ }^{2}$ (acres) & $5.08( \pm 1.4)$ & $1.14( \pm 0.3)$ & $-2.70^{* *}$ \\
Distance to forest (min walking) & $77.97( \pm 0.53)$ & $88.04( \pm 0.49)$ & 1.11 \\
\hline Dichotomous predictors & \% of beekeepers & $\mathbf{\%}$ of non-beekeepers & \multirow{2}{*}{ ( value } \\
\hline Honey hunter (yes) & $32.90( \pm 0.46)$ & $10.43( \pm 0.26)$ & $23.87^{* * *}$ \\
Parental beekeeping (yes) & $72.26( \pm 0.68)$ & $47.85( \pm 0.55)$ & $19.68^{* * *}$ \\
Engaged in livestock keeping (yes) & $80.65( \pm 0.72)$ & $53.99( \pm 0.59)$ & $25.53^{* * *}$ \\
HH head having no formal education & $18.07( \pm 0.03)$ & $24.54( \pm 0.03)$ & 0.16 \\
\hline
\end{tabular}

1 Using the OECD-modified scale: Household head $=1$, each additional adult $=0.5$, each child $=0.3$

2 Comprises natural and planted forest areas as well as orchards

${ }^{*}$ significance at $5 \%,{ }^{* *}$ significance at $1 \%,{ }^{* * *}$ significance at $0.1 \%$

Stepwise backward binary logit regression identified significant relationships between beekeeping uptake and the size of forest area owned, engagement in honey hunting, parental beekeeping and engagement in livestock keeping (Figure 2, Appendix C). The pseudo $\mathrm{R}^{2}$ (1- residual deviance/null deviance) for our beekeeping adoption model was 0.248 . The distribution of the residuals indicated that the logit link function was a suitable choice. Random effects for subvillage affiliation as well as $2^{\text {nd }}$ degree interactions were also tested for the model, but did not improve the model fit, i.e. did not 


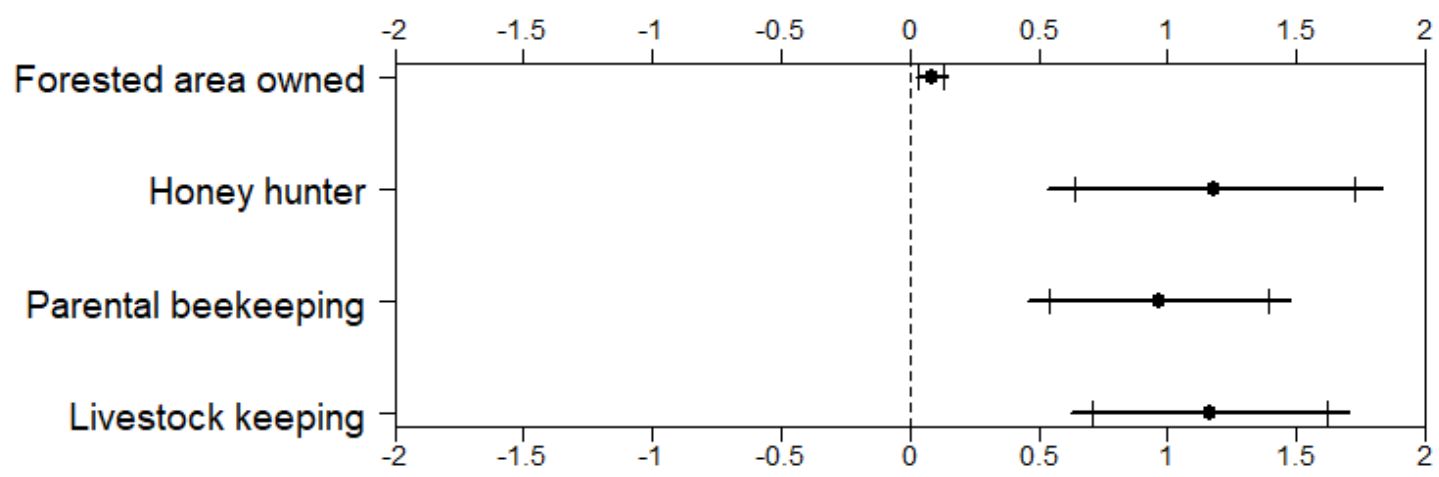

Figure 2. - Estimated coefficients, standard errors, $90 \%$ and $95 \%$ confidence intervals of binary logit regression model of beekeeping adoption (Sample size: 155 beekeepers, 163 non-beekeepers) (see Appendix C for model statistics).

Interviewed beekeepers and non-beekeepers also stated that tribal cultural tradition in beekeeping (or the lack of) was an important driver (or inhibitor) of beekeeping adoption:

"But here the Sandawe people used to be beekeepers for a long time and they used to hunt bees from the trees. But I am Wagogo, we don't have this culture from our grandfather, [we are] not engaged in beekeeping." (male non-beekeeper, 60)

While the reasons for a link between beekeeping adoption and livestock keeping or honey hunting respectively were not evident from our qualitative data, the inheritance of bee hives from parents and grandparents as a reason for beekeeping adoption was a recurrent theme in interviews conducted with beekeepers. The link between size of forested land owned and beekeeping adoption is further supported by repeated mentions of shortage of land resources for beekeeping:

"[...] there is no empty space where we can place beehives, we are supposed to go and look for a place and find who owns that place and have to request or rent for placing hives." (female beekeeper, 46),

as well as mentions of the lack of safety of hives on general land: though it is community forest, but I am not sure of the security in that place. If I started beekeeping I would put hives on my own land." (male non-beekeeper, 44). 
Lastly, many interview respondents also indicated courage as a necessary character attribute of a beekeeper.

322 On examination of interview data on possible causes for theft being such a pervasive problem and the predominant reason for giving up beekeeping, we found emerging themes regarding a general lack of resources, unclear tenure arrangements, preferential treatment of beekeeping groups as well as added security modern hives. Respondents stated that insecure tenure rights of forested areas on central government owned unreserved land led to an increased occurrence of hive theft. The large distances to land reserved for beekeeping activities, where some level of protection against theft is provided by the local authorities, is an inhibiting factor for some beekeepers. Traditional hives were more likely to be stolen than modern hives (frequently donated by development organizations) as the latter were perceived to be 'official' and therefore more respected by the general public who were fearful of the authorities:

"For the modern hives, is good, because people here respect when they see a modern hive, they regard it as a government property, so they cannot touch it because they are afraid of getting caught." (male beekeeper, 77)

Several respondents also reported that beekeepers who were organized in official beekeeping associations and had received modern hives from support organizations were extended increased protection by law-enforcers. This has led to increased protection from theft as well as improved access to land reserved for beekeeping, where other forest activities are excluded.

\subsection{Determinants of dependence on beekeeping for subsistence and income}

Given the relatively limited nutritional value of honey, it is perhaps not surprising that only $10 \%$ percent of beekeepers indicated a dependence on beekeeping products for subsistence of $30 \%$ and more. More unexpected however was that almost half of all the beekeepers in our study (45\%) indicated zero dependence on beekeeping for subsistence. We found significant associations between dependence on beekeeping for subsistence and several potential predictor variables (Table 2, Appendix D), including length of engagement in beekeeping, honey hunting, motivation for beekeeping adoption as well as source of beekeeping training received. Only $23 \%$ of beekeepers indicated a dependence on beekeeping for income of $30 \%$ or more within their livelihood portfolios. Approximately the same number of beekeepers did not gain any income from beekeeping at all. We found significant associations between dependence on beekeeping as an 
income source and several predictor variables, including length of engagement in beekeeping, motivation for beekeeping adoption and beekeeping group membership.

Table 2. - Continuous (Pearson's coefficient of correlation, $r$ ) and dichotomous (t-test) predictors for percentage of beekeeping dependence (subsistence and cash income) (see Appendix D for all tested variables).

\begin{tabular}{|c|c|c|c|c|}
\hline Continuous predictor & 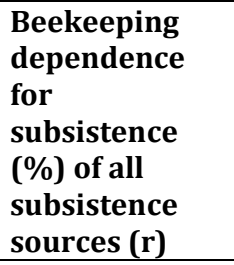 & t-value & $\begin{array}{l}\text { Beekeeping } \\
\text { dependence } \\
\text { for cash } \\
\text { income }(\%) \text { of } \\
\text { all income } \\
\text { sources }(r)\end{array}$ & t-value \\
\hline Length of beekeeping activity (years) & 0.22 & $2.702^{* *}$ & 0.20 & $2.485^{*}$ \\
\hline Dichotomous predictors & Yes (No) mean & & Yes (No) mean & \\
\hline Honey hunter & $14.22(8.10)$ & $-3.427^{* * *}$ & $18.63(21.97)$ & 1.100 \\
\hline Motivation for beekeeping uptake - income from honey & $10.56(6.47)$ & -1.493 & $22.21(10.00)$ & $-3.003^{* *}$ \\
\hline Motivation for beekeeping uptake - income from wax & $7.55(14.64)$ & $4.124^{* * *}$ & $24.09(15.18)$ & $-3.127^{* *}$ \\
\hline Motivation for beekeeping uptake - food & $12.41(3.50)$ & $-4.612^{* * *}$ & $18.57(27.50)$ & $2.256^{*}$ \\
\hline Motivation for beekeeping uptake - medicine & $16.71(6.88)$ & $-5.814^{* * *}$ & $16.47(23.03)$ & $2.364^{*}$ \\
\hline Beekeeping learned from - family member & $11.88(6.40)$ & $-3.131^{* *}$ & $21.67(19.20)$ & -0.767 \\
\hline Beekeeping learned from - self-taught & $4.21(10.94)$ & $2.945^{* *}$ & $18.68(21.18)$ & 0.535 \\
\hline Beekeeping learned from - government training & $3.00(10.60)$ & $4.232^{* * *}$ & $17.50(21.10)$ & 0.707 \\
\hline Member of beekeeping group & $10.31(10.02)$ & 0.149 & $26.15(18.51)$ & $-2.412^{*}$ \\
\hline
\end{tabular}

* significance at $5 \%,{ }^{* *}$ significance at $1 \%,{ }^{* * *}$ significance at $0.1 \%$

We analyzed the dependence on beekeeping for either subsistence and/or income in two separate models. The binary component of a fractional regression model for subsistence dependence determines if someone is to at least some degree (i.e. more than $0 \%$ ) dependent on beekeeping for subsistence (zero vs non-zero dependence proportion). We identified significant relationships between non-zero dependence for subsistence and several variables. These included engagement in honey hunting and income from wax as motivation for beekeeping uptake (negative relationship), food and medicine provision as motivations for beekeeping uptake, as well as being self-taught in beekeeping techniques (negative relationship) (Figure 3). The fractional model component explains the distribution of non-zero levels of beekeeping dependence for subsistence. It revealed significant relationships between level of dependence on beekeeping for subsistence and length of engagement in beekeeping as well as external training received in beekeeping technical knowledge by a government organization (negative relationship) (Figure 3, Appendix E). 


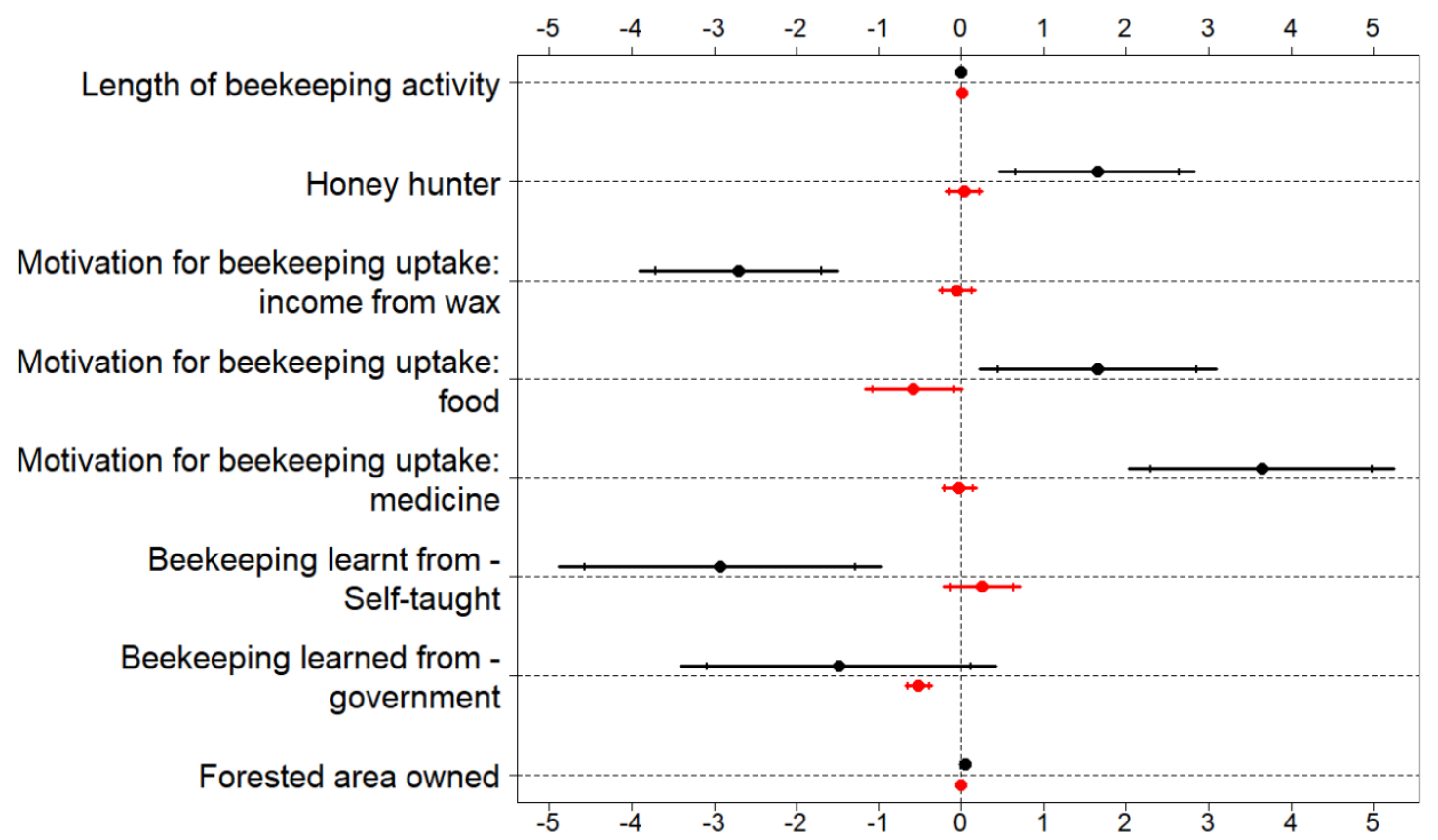

372 Figure 3. - Estimated coefficients, standard errors, $90 \%$ and $95 \%$ confidence intervals of binary 373 logit (black) and fractional (red) components of a two-part regression model for beekeeping 374 dependence for subsistence (Sample size: 155 beekeepers) (see Appendix E for model statistics).

Through fractional regression modelling of dependence on beekeeping as an income source, we identified significant relationships between non-zero dependence for income (binary model component) and the following variables: income from honey and wax being one of the motivations for beekeeping uptake, beekeepers living closer to the forest (negative estimate implying that beekeepers closer to the forest have a higher probability of non-zero dependence) as well as being members of a beekeeping group (Figure 4, Appendix F). The fractional model component for the regression model of beekeeping dependence for income, which explains the variability of non-zero levels of dependence, showed significant relationships for increasing living distance from a major road, with provision of medicine as a beekeeping uptake motivation (negative) as well as the length of engagement in beekeeping (Figure 4, Appendix F). 


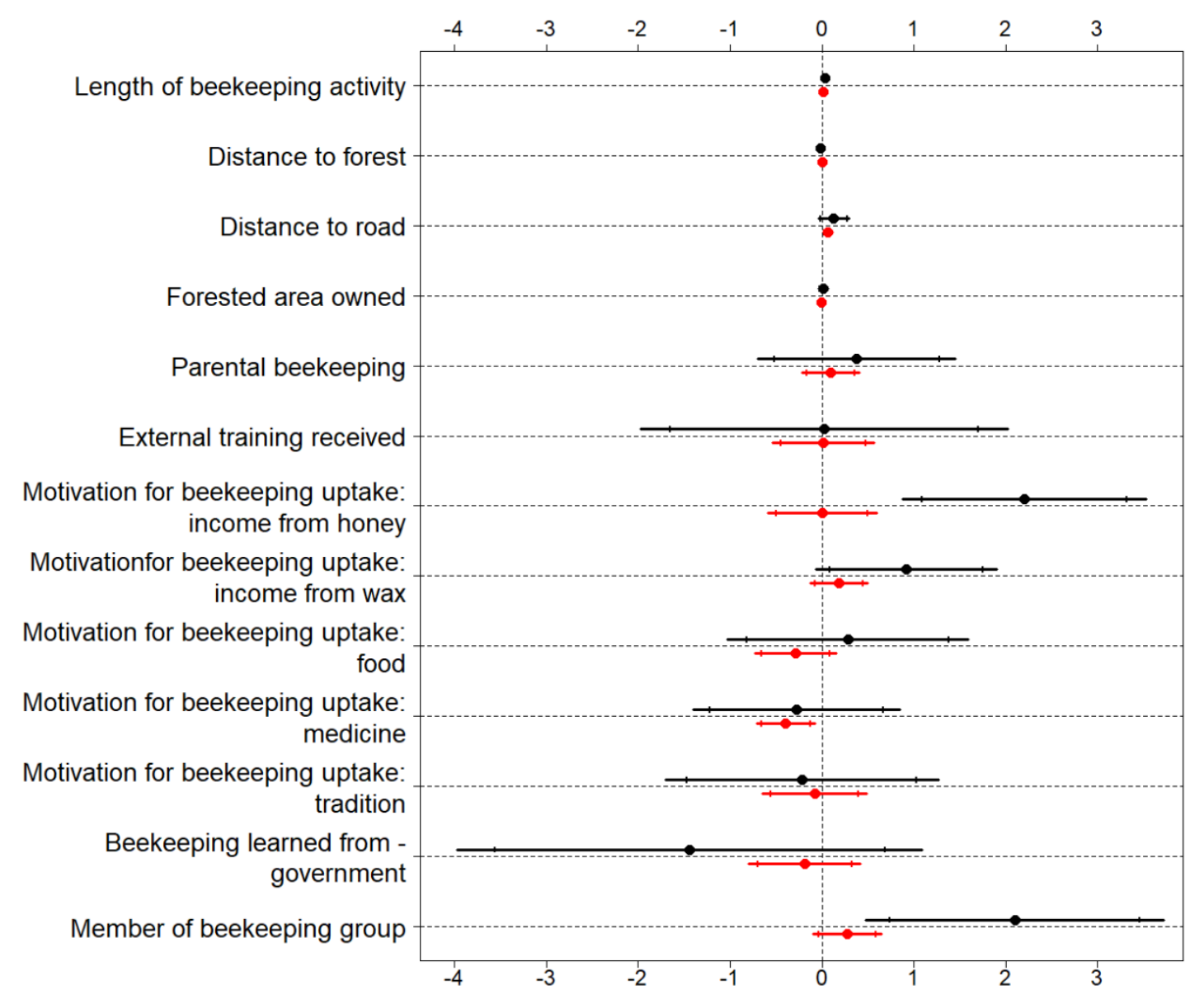

Figure 4. - Estimated coefficients, standard errors, $90 \%$ and $95 \%$ confidence intervals of binary logit (black) and fractional (red) components of a two-part regression model for beekeeping dependence for income (Sample size: 155 beekeepers) (see Appendix F for model statistics).

\subsection{Determinants of beekeeping success}

Beekeepers $(n=155)$ cited drought (66\%), theft (53\%) and pests (44\%) as the three most frequent problems affecting success in their beekeeping activities. Interview respondents indicated that harvest levels were generally very low compared to the period preceding the drought. They pointed out that many recently trained beekeepers had abandoned beekeeping due to very low honey production during the preceding drought years. In contrast, more experienced beekeepers were more aware of climate-induced harvest fluctuations and were more likely to continue with beekeeping activities despite temporary setbacks (Fisher, 1996).

"Q: Why did you stop beekeeping? A: [Because of] climate change: nowadays you can go to hives and you find no bees enter the hive. Q: And that is because the climate has changed? A: Nowadays there are no more bees and sometime when I go there is brood but no honey, so that discouraged me from beekeeping." (male ex-beekeeper, 31) used here as a variable for success in beekeeping, and predictor variables revealed several 
significant associations including source of training received and indication of no training required 407 (Table 3, Appendix G).

Table 3. - Continuous (Pearson's r) and dichotomous predictors (two sample t-test of mean values of each outcome, i.e. yes/no) for beekeeping success measure (liters of honey harvested in the preceding 12 months) (Sample size: 155 beekeepers) (see Appendix G for all tested variables).

\begin{tabular}{lcc}
\hline Continuous predictors & Harvest quantities (r) & t-value \\
\hline Age (years) & -0.139 & -1.620 \\
HH size (Adult equivalent) & 0.019 & 0.220 \\
Distance to road (km) & $0.191^{*}$ & 2.261 \\
Forest area owned (acres) & $0.187^{*}$ & 2.216 \\
Length of beekeeping activity (years) & 0.078 & 0.897 \\
\hline Dichotomous predictors & Yes (mean liters & No (mean liters \\
& harvested) & 32.955 \\
Engaged in livestock keeping & $11.960^{* *}$ & 5.125 \\
Beekeeping learned from - government training & $30.612^{* *}$ & 5.750 \\
Does not require training & $30.574^{* *}$ & 31.217 \\
Knowledge in hive placement & $14.353^{*}$ &
\end{tabular}

${ }^{*}$ significance at $5 \%,{ }^{* *}$ significance at $1 \%,{ }^{* * *}$ significance at $0.1 \%$

412 We identified a significant negative relationship (fractional regression modelling) between non413 zero harvest quantities and the beekeeper having been trained in beekeeping by a governmental 414 organization. While beekeepers taught by a governmental organization had been active beekeepers for about half of the time than those taught by family/community members, the length of engagement in beekeeping was not a significant predictor of beekeeping success. We also found a significant negative relationship with the beekeeper indicating that they do not require further training (Figure 5, Appendix $\mathrm{H}$ ). The variation of harvest quantities larger than zero was significantly positively affected by area of forests owned and engagement in livestock keeping (Figure 5, Appendix H). 


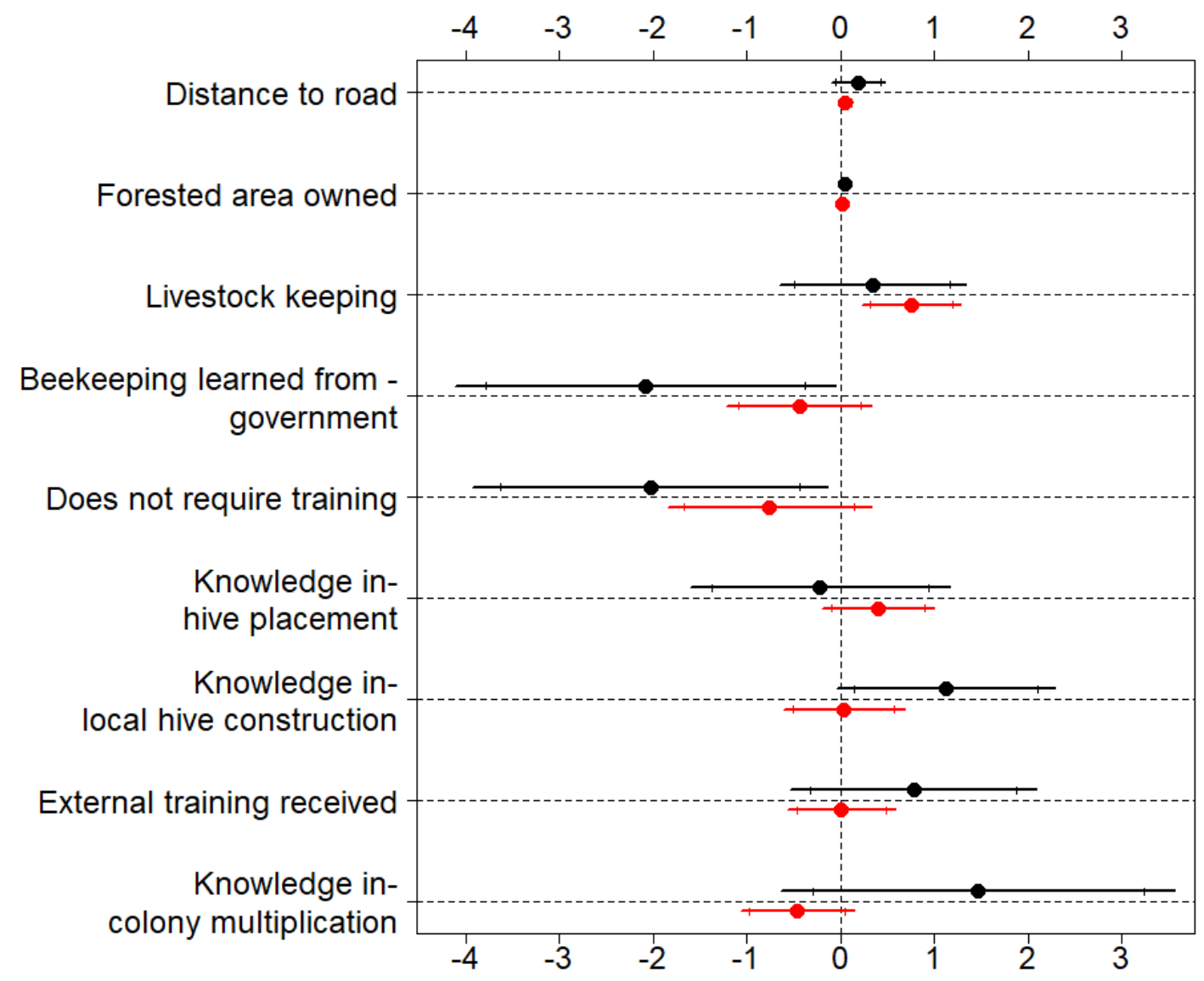

422 Figure 5. - Estimated coefficients, standard errors and 95\% confidence intervals of binary logit 423 (black) and fractional (red) components of a two-part regression model for beekeeping success 424 (Sample size: 155 beekeepers) (see Appendix H for model statistics).

\subsection{Existing technical capacities and needs}

427 Farmers currently engaged in beekeeping recalled having received external technical beekeeping training from a governmental or non-governmental organization mainly on the topics of honey harvesting and processing (93\%), hive placement (48\%), construction of modern hives, proper hive inspection and other beehive product processing (all 21\%). Most active beekeepers learned beekeeping from a family member (68\%) followed by a neighbor or other village member $(19 \%)$ or were self-taught $(12 \%)$. Only a small proportion of beekeepers learned beekeeping through governmental or non-governmental capacity building organizations ( $6 \%$ and $3 \%$ respectively). Most respondents who were engaged in beekeeping in the past, but have since given up, learned beekeeping from their family members (67\%). This training included hive placement (86\%), honey harvesting and processing (83\%) and construction of traditional hives (79\%). Beekeepers most frequently named hive placement (88\%), traditional hive construction and honey harvesting and processing (both $81 \%$ ) as the aspects of beekeeping they possess knowledge over. Technical knowledge aspects, which were cited as desired but not yet owned by beekeepers were mainly 
honey harvesting and processing (61\%), modern hive construction (54\%) and pest and disease control $(48 \%)$.

\subsection{Beekeeping associations}

While we did not specifically set out to examine the dynamics of beekeeping associations, through inductive analysis of our interview data we found evidence of continued group cohesion after support ended in only one case. This was where yearly follow-up visits by the project team were carried out over several years. In interviews, beekeeping group members perceived little to no benefit from collective action. Whilst many interview respondents saw advantages in joining beekeeping associations in principle (i.e. improved market access; security; knowledge sharing; pooling of resources), they indicated that beekeeping groups face a multitude of internal problems related to lack of transparency, leadership, market knowledge, capacity to produce economies of scale and member buy-in to the associations' goals.

"In a group it is easier to get training, get equipment from donors who want to support beekeeping activities. Also the bylaw operates more for the beekeeping groups than for individuals. So e.g. if they have hives in a group and someone goes and destroys them or steals the honey, if he is caught and sent to the government, the law is more acted on than if the person had destroyed an individual persons property. Also in a group, if there are several people, if he e.g. does not have time, it is possible that someone from the group can go and patrol. They can set up a timetable of who patrols when and that is good for security of the hives." (male beekeeper, 41)

"There is bad leadership, because the group was given responsibility of that forest to ensure no cows go there to graze, but other villagers they used to give money to the group leader and the leader allowed them to send their cattle to graze in the forest. It created a lot of conflict and the group collapsed." (male beekeeper, 51)

Furthermore, interview data suggests that access to these associations is made difficult for those who are not able to pay the requested entry fee. While several interview respondents indicated that participants for beekeeping training were self-selected during village meetings, several other respondents reported instances of elite capture of project benefits as less well-connected community members or people living on the geographical edges of community boundaries were overlooked when invitations were issued to participate in the project and to join associations. They were subsequently precluded from access to training and possible equipment distribution.

"I heard that there was beekeeping training, but I was not involved. Because here, when something like this happens the leaders call their own friends. Because sometimes you can get something else (i.e. equipment for example) from the training. So I was not part of the friends of the leaders." (male beekeeper, 38) 


\section{Discussion}

478 Given how widely promoted beekeeping as an alternative livelihood strategy is, there is very little 479 empirical evidence of the effectiveness of these interventions aiming to integrate conservation and development goals (Roe et al. 2014, Brooks et al. 2006b). Blom et al. (2010) find that these projects often fail as the complexity of rural communities is ignored. This study is an attempt to begin to close the knowledge gap on how the targeting and delivery of beekeeping interventions need to be designed in order to take account of local circumstances and the reality of rural beekeepers in Tanzania. We identified key drivers influencing beekeeping uptake, dependence and success, which may be critical to the design of future beekeeping technical assistance programs. The appropriate targeting of beneficiaries and the nature of capacity building for beekeeping influence the long-term outcome of interventions as they become relevant to local communities and correspond to their motivations and needs.

\subsection{Adoption and abandonment of beekeeping as a livelihood activity}

\subsubsection{Key factors influencing adoption of beekeeping}

Beekeeping adoption was contingent upon whether parents had previously kept bees as a livelihood activity. While the inheritance of hives from parents is a logical explanation for this, another conceivable explanation might be that through parental beekeeping younger generations can acquire beekeeping skills from a young age (Fisher, 2000). This also suggests that tradition is an important factor in the uptake of beekeeping - a point which was supported by our qualitative data analysis. Support organizations may wish to consider this when deciding on beneficiary selection criteria for beekeeping projects to avoid working against cultural preferences.

Adoption was also more likely if the respondent simultaneously practiced honey hunting i.e. the collection of honey from wild bees. The reason for this might be that honeyhunters are familiar with bees as well as the use of honeybee products. Whether an individual was a beekeeper or not was also contingent on them keeping livestock. An explanation for this phenomenon could be that livestock keepers spend more time in the forest while grazing their herds than farmers. This gives them the opportunity to locate and plunder wild bee nests, thus becoming more familiar with bees and aware of the benefits of honeybee products. Given that honey hunting and livestock keeping seem to be conducive to the adoption of beekeeping, selecting participants with these backgrounds for beekeeping promoting interventions could reduce project attrition and enhance adoption of beekeeping.

Lastly, beekeeping adoption was also predicted by the size of forested land owned, suggesting that beekeeping is not necessarily an activity that is without land requirements as purported by some authors (FAO, 2011; Jacobs et al., 2006). Planning beekeeping interventions in locations with limited access to forested land for participants could undermine project outcomes.

512 When asked about their individual motivation to become a beekeeper, the most important reasons 513 were the expectation of income from honey sales, followed by supplementary food provision. This information may help guide NGOs and government organizations to target and promote the benefits of beekeeping to beneficiary communities more effectively. 


\subsubsection{Key factors influencing rejection of beekeeping}

Some respondents were dissuaded from adopting beekeeping due to a lack of capital, available land and relevant knowledge, indicating that the initial investment, space and technical knowledge requirements of beekeeping are non-trivial contrary to some authors' suggestions (Nel and Illgner, 2004). The expectation that modern hive donation leads to trickle-down benefits, i.e. the adoption of modern hive technology by other community members over time, needs to be carefully managed, as a lack of capital to purchase modern hives can be inhibitive (Carroll et al., 2017; Tesfaye et al., 2017). Land availability is critical to increasing beekeeping uptake (Jayne et al., 2014), as hives located away from homesteads are often damaged or stolen. The consideration of respondent land access and tenure as a critical component of participant recruitment may reduce beekeeping project attrition. Access could for example be improved through the designation of beekeeping reserves, which are accessible to all beekeepers in the community. Finally, there was awareness among respondents of the significant challenges posed to successful beekeeping if the supporting technical assistance was absent. While some new activities might be adopted through a learning by doing' approach, our results indicate that this is not the case for beekeeping. This suggests that beekeeping project participants may benefit from a greater emphasis on building technical capacities appropriate to the specific context of each project location.

Fear of bees was one of the most frequently cited reasons for not adopting beekeeping by nonbeekeeping respondents whose parents were beekeepers. Managing Apis mellifera scutellata (the most common honey bee sub-species in Central and Eastern Africa) is challenging due to its highly defensive behavior (Ellis and Ellis, 2008). Even when there is a family history in beekeeping, some offspring are unwilling to adopt the activity to boost their income. Interview data confirms beekeeping as a potentially perilous activity, particularly as African beekeeping is still largely practiced in forested environments, which can pose significant dangers to humans through contact with wildlife and insect transmitted diseases (Lawton, 1982). Successfully overcoming the apprehension of bees may be contingent on the level of training and protective equipment provided.

\subsection{3. $\quad$ Reasons for abandoning beekeeping}

Theft of honey and hives was cited as the most common cause of beekeeping abandonment, due in part to the increasing value of honey as a commercial product and the growing difficulty in obtaining raw materials for the construction of hives. For example, obtaining whole tree stems necessary for the construction of traditional log hives is becoming more and more difficult due to increasing restrictions on forest resource use, as well as increasing levels of deforestation, according to several interviewed beekeepers. Theft is rarely addressed by beekeeping support organizations yet appears to be a significant concern of beekeepers. If organizations continue to ignore this aspect of beekeeping development, then there is the possibility that they will undermine their own project outcomes and fail to augment recruits to their programs. Secure access to forested areas for the sourcing of hive materials and increased protection of these areas by local authorities for beekeeping use could prove to be helpful in tackling the issue of theft. 


\subsection{Factors influencing dependence on beekeeping for subsistence and as an income source}

We hypothesized that individuals with a higher dependence on beekeeping for subsistence differed in location, social situation, history in beekeeping and livelihood strategies than those who were more dependent on beekeeping as an income generating activity

\subsubsection{Motivation for adopting beekeeping}

The initial adoption of beekeeping was motivated by different factors for those more dependent on beekeeping for subsistence than for those more dependent on beekeeping as an income generating activity. Farmers who used beekeeping as an income generating activity were more likely to indicate income from honey and wax as a motivation, rather than for the provision of traditional medicine. Conversely, subsistence dependence demonstrated a significant negative relationship with income from beehive products as ex-ante adoption motivation and an increased tendency to engage in honey hunting. While recollection may limit the accuracy of the stated ex-ante motivation, this suggests that households that were more dependent on honey as a calorie source regarded the procurement and use of honey with a less commercial sense than households that were more dependent on honey as an income source. Further, we observed a negative relationship between the level of dependence on beekeeping for subsistence and having received initial training in beekeeping from a governmental organization. This suggests that those individuals who received formal training were more inclined to treat beekeeping as an income rather than a food source. We suggest that if typologies of divergent motivations to harvest bee products are taken into account during participant selection for beekeeping support programs a higher continuation rate of newly trained beekeepers could be achieved. Furthermore, honey harvesting techniques with the aim of commercialization of the end product might be more complex to those aimed for home consumption. Training participants who do not intend to sell their harvest in these more complex techniques may be of little use to them. All in all, more precise targeting of beekeeping interventions according to participants needs and wishes could improve the overall outcome.

\subsection{2. $\quad$ Access to resources}

Proximity to forests influenced the dependence on beekeeping as an income generating activity, as access to resources such as bee forage is an important factor in any beekeeping production system. When beekeeping is promoted by support organizations for income generation, the consideration of the question of sustainable access of project beneficiaries to forest resources may help ensure the necessary input factors.

\subsubsection{Membership in a beekeeping association}

Most external capacity building efforts require farmers to form informal collectives before receiving training and equipment provision (Affognon et al., 2015; Carroll et al., 2017). This may be done for one or more of the following reasons: to enable more efficient delivery of training, to allow knowledge sharing, to create economies of scale through marketing as a group as well as to share responsibilities around the apiaries. Beekeeping group membership was an important determinant of whether a respondent used beekeeping as an income generating activity. Membership was not a significant determinant of dependence on beekeeping for subsistence. Our interview data suggests a mismatch between expectations towards beekeeping associations and the reality they deliver. Evidence of long-term group cohesion was found only in the case where continued and regular follow-up support was provided from the intervening organization - in itself a phenomenon rarely 
observed in beekeeping projects (Carroll et al., 2017). Elite capture of project benefits through better connected and more centrally living community members has left several community members missing out on the opportunity to receive training and equipment donations (Platteau, 2004). Further, a lack of transparency within beekeeping groups has left several community members question the fairness of how benefits were distributed. The commonly applied project requirement of grouping together project beneficiaries in associations thus needs to be handled with care by beekeeping support organizations: transparency, members' buy-in and inclusiveness of groups might be enhanced by establishing clearly defined outcome indicators for both, participants and support organizations as well as advertising the possibility of training and access to a beekeeping group more thoroughly within communities; the promise of improved market access through economies of scale and value-added products requires an increased access to honey processing equipment as well as more thorough baseline studies of bee forage availability and thus potential to produce the quantities of bee products needed for larger markets; regular follow-up through more investment in local extension service providers may ensure overall group success and cohesion. In this context further research is needed to estimate the relative benefits of investing a part of project budgets into organizations that can provide extension services versus investing in the donation of more hives to beneficiaries. In summary, there is a large body of literature available on producer organizations and determinants of their sustainability (Fischer and Qaim, 2014; Markelova et al., 2009; Shiferaw et al., 2011), but our results suggest that the application of this knowledge by practitioners in the beekeeping sector is thus far lacking.

\subsubsection{Length of engagement in beekeeping}

The level of dependence for both subsistence and income-motivated beekeepers was related to the number of years spent beekeeping, suggesting that experience is critical to an individual's intensity of engagement in beekeeping. If the goal is to promote the engagement in beekeeping, longer-term educational support provided over extended time-scales may be beneficial (Carroll et al., 2017). Beekeeping demands the knowledge of a range of different techniques throughout a beekeeping season. Conditions for beekeeping can vary significantly between seasons contingent upon regional weather patterns. Extension services tailored to the technical knowledge needs of beekeepers throughout several beekeeping seasons could thus contribute to the increased sustainability of interventions by adapting to the both the beekeepers needs and the contingencies of unpredictable weather conditions. This type of capacity building support could engage locally successful and experienced beekeepers as champions and trainers. These trainers could provide valuable knowledge of local conditions and are likely to enjoy acceptance and trust by local community members. The logistics of employing locally present personnel is also more cost-effective than externally sourced beekeeping experts.

\subsection{Success as a beekeeper}

The three years preceding this study were marked by severe drought conditions in the study region. During interviews, drought was also the most frequently cited challenge faced by beekeepers, in some cases even leading to giving up beekeeping altogether among less experienced beekeepers. This draws attention to the necessity of taking seasonal changes in local climate into consideration when designing beekeeping capacity building and support interventions in order to manage expectations of success of project participants (Fisher, 1996). An analysis of most frequently recalled topics taught in the context of such external interventions shows that only the very basic technical knowledge of hive placement and harvesting was passed on to the majority of 
643 training beneficiaries. Most of the respondents in receipt of formal training (i.e. not by family or 644 community members) had received a maximum of three days training. The brevity of such training 645 fails to reflect the complex skill-set required for a successful beekeeper (Amulen et al., 2017; Carroll 646 et al., 2017).

647 Whether a beekeeper managed to harvest any honey at all in the twelve months preceding our 648 study, was negatively related to the individual having received beekeeping training by a 649 government organization. This negative relationship suggests either that the quality of training 650 provided was so low that it was insufficient to generate any harvest or that the targeting of project 651 participants was not ideal or both. We propose that capacity building efforts by governmental 652 organizations need to be more precisely targeted towards individuals whose livelihood strategies, 653 proximity to the forest and family history are most conducive to beekeeping. We also suggest that 654 beekeeping training is improved, in order to render the beneficiaries of such trainings capable of 655 achieving at least the same beekeeping results as their family/community-trained peers. As 656 discussed above, these improvements might entail: more intensive training on locally appropriate 657 beekeeping systems and construction of hives based on locally available resources, subsequent 658 extension services to provide follow-up support throughout several beekeeping seasons, training 659 provided by locally successful and experienced beekeepers, while the need for protective 660 equipment and land access of project beneficiaries are kept in consideration.

661 In our study communities, size of forested area owned was also an important predicting factor of 662 beekeeping success. This supports our claim that beekeeping is not necessarily a suitable activity to 663 be promoted as a solution to landless rural populations (Nel and Illgner, 2004).

664 Whilst the suitability of modern beehives for African bee species is disputed (Ingram and Njikeu, 665 2011), a majority of surveyed beekeepers indicated a desire to learn how to construct such hives. 666 We conclude that at least the promotion of this type of hives by governmental and non667 governmental organizations among the rural populations of Central Tanzania, has been successful. 668 Whether or not the expectations of higher yields and better-quality hive products raised in this way 669 are justified, particularly without appropriate training support, remains to be determined. 


\section{Conclusion}

672 In analyzing predictors of beekeeping uptake, dependence and success we have identified a range

673 of factors that need to be considered during the planning of beekeeping interventions: 1 .

674 Beneficiary selection needs to be culturally sensitive in order to target those population groups that

675 are most likely to incorporate beekeeping into their portfolio of livelihood activities. 2 . Access to

676 land, technical knowledge and capital to purchase hives determine farmers' decisions to adopt

677 beekeeping. The consideration of these points may thus need to form the cornerstones of

678 beekeeping projects. 3. The noticeable shift from beekeeping for food procurement to an income

679 generating activity, with implications for the macro-economic output of beekeeping, is partly fueled

680 by beekeeping training projects. This may have implications for the selection of future project sites

681 and alignment with national beekeeping policy goals. 4. The distribution of hives by NGOs and the

682 Government may be less critical to adoption than the provision of protective equipment. 4. The

683 widespread theft of honey and hives is an issue that could undermine project outcomes, but for

684 which no straightforward solution can be suggested. 5. The often-required group membership of

685 projects tends to create division in project communities and needs to be handled with more care.

686 Lastly, more comprehensive training, delivered by locally experienced beekeepers and regular

687 technical follow-up support is needed to equip future beekeepers with the necessary skills to

688 continue their beekeeping activities in the face of arising challenges. Our study attempted to start

689 closing the knowledge gap around how beekeeping interventions need to be targeted and delivered

690 in order to achieve better long-term adoption of locally appropriate beekeeping techniques. We

691 believe that this will determine the overall livelihood and conservation outcomes of alternative

692 livelihood projects, in which beekeeping seems to be playing a key role.

693 As beekeeping is widely promoted as an alternative livelihood activity that provides potential

694 conservation incentives to the rural poor, future research should investigate the impacts of

695 beekeeping on poverty alleviation as well as conservation behavior in beekeeping communities.

696 


\section{Appendices}

Appendix A. - Study communities

\begin{tabular}{|c|c|c|c|c|}
\hline & Msemembo & Sasilo & Kwa Mtoro & Paranga \\
\hline Region & Singida & Singida & Dodoma & Dodoma \\
\hline District & Manyoni & Manyoni & Kondoa & Chemba \\
\hline Population & 5978 & 11987 & 2055 & 2000 \\
\hline $\begin{array}{l}\text { Forest area (ha) per } \\
\text { person }\end{array}$ & 2.3 & $\begin{array}{l}\text { unknown ( } 60 \text { ha } \\
\text { owned by } \\
\text { community + small } \\
\text { private forest areas } \\
\text { of unknown size) }\end{array}$ & $\begin{array}{l}\text { unknown ( } 20 \text { ha in } \\
\text { general use }+ \\
\text { reserved forest of } \\
\text { unknown size) }\end{array}$ & 1.3 \\
\hline $\begin{array}{l}\text { Participatory Forest } \\
\text { Management in place }\end{array}$ & $\begin{array}{l}\text { Planned: Joint Forest } \\
\text { Management of } 11536 \\
\text { ha }\end{array}$ & $\begin{array}{l}\text { PFM for } 100 \text { ha } \\
\text { shared with } \\
\text { neighboring village }\end{array}$ & No & No \\
\hline $\begin{array}{l}\text { Distance to district } \\
\text { market }\end{array}$ & $33 \mathrm{~km}$ & $72 \mathrm{~km}$ & $65 \mathrm{~km}$ & $50 \mathrm{~km}$ \\
\hline $\begin{array}{l}\text { Reserved land for } \\
\text { beekeeping (ha) }\end{array}$ & 730 & 60 , but not enforced & Yes, size unknown & No \\
\hline $\begin{array}{l}\text { Beekeeping projects in } \\
\text { the past }\end{array}$ & $\begin{array}{l}\text { 2007: District Gov.; } \\
\text { 2013/14: World } \\
\text { Vision, TFS; SIDO and } \\
\text { TFF (unknown year) }\end{array}$ & $\begin{array}{l}\text { 1999 - 2004: } \\
\text { NORAD }\end{array}$ & $\begin{array}{l}\text { TSF, TASAF, World } \\
\text { Vision, CREDEP, } \\
\text { District Government } \\
\text { (years unknown) }\end{array}$ & 2012: TASAF \\
\hline $\begin{array}{l}\text { Beekeeping group } \\
\text { existent }\end{array}$ & Yes, but shrinking & $\begin{array}{l}\text { Yes, but not } \\
\text { functional }\end{array}$ & 2 functional groups & Yes \\
\hline
\end{tabular}


Appendix B. - Table of two-sample comparisons of the means of possible predictors (continuous and dichotomous) of beekeeping adoption

\begin{tabular}{|c|c|c|c|c|}
\hline Continuous predictors & $\begin{array}{l}\text { Beekeepers } \\
\text { mean }( \pm S E)\end{array}$ & $\begin{array}{c}\text { Non- } \\
\text { beekeepers } \\
\text { mean }( \pm \text { SE) }\end{array}$ & t value & p value \\
\hline Age & $49.03( \pm 1.7)$ & $50.56( \pm 1.2)$ & 0.90 & 0.367 \\
\hline HH size (Adult equivalent ${ }^{1}$ ) & $2.79( \pm 0.1)$ & $2.50( \pm 0.1)$ & -2.35 & 0.020 \\
\hline Distance to forest (min walking) & $77.97( \pm 0.5)$ & $88.04( \pm 0.5)$ & 1.11 & 0.268 \\
\hline Distance to road (km) & $1.10( \pm 0.2)$ & $1.17( \pm 0.2)$ & 0.22 & 0.826 \\
\hline Forested area owned ${ }^{2}$ (acres) & $5.08( \pm 1.4)$ & $1.14( \pm 0.3)$ & -2.70 & 0.008 \\
\hline Length of stay in community (years) & $40.51( \pm 1.3)$ & $39.03( \pm 1.3)$ & -0.78 & 0.439 \\
\hline Dichotomous predictors & $\begin{array}{c}\text { Beekeepers \% } \\
\text { ( } \pm \text { SE) }\end{array}$ & $\begin{array}{c}\text { Non- } \\
\text { beekeepers \% } \\
( \pm \text { SE) }\end{array}$ & $\chi^{2}$ value & p value \\
\hline HH head education (no formal education) & $18.07( \pm 0.34)$ & $24.54( \pm 0.40)$ & 1.98 & 0.159 \\
\hline HH head education (secondary/techn. school) & $3.65( \pm 0.15)$ & $10.00( \pm 0.25)$ & 2.39 & 0.123 \\
\hline Honeyhunter (yes) & $32.90( \pm 0.46)$ & $10.43( \pm 0.26)$ & 23.87 & $<0.001$ \\
\hline Parental beekeeping (yes) & $72.26( \pm 0.68)$ & $47.85( \pm 0.55)$ & 19.68 & $<0.001$ \\
\hline Engaged in livestock keeping (y) & $80.65( \pm 0.72)$ & $53.99( \pm 0.59)$ & 25.53 & $<0.001$ \\
\hline
\end{tabular}

\footnotetext{
${ }^{1}$ Using the OECD-modified scale: Household head $=1$, each additional adult $=0.5$, each child $=0.3$ (http://www.oecd.org/eco/growth/OECD-Note-EquivalenceScales.pdf)

${ }^{2}$ Comprises natural and planted forest areas as well as orchards
} 
702 Appendix C. - Estimated parameters of a binary logit regression model of beekeeping adoption

\begin{tabular}{lccc}
\hline & Coefficient & SE & z value \\
\hline Intercept & -1.844 & 0.298 & $-9.199^{* * *}$ \\
Forested area owned (acres) & 0.082 & 0.031 & $2.686^{* *}$ \\
Honey hunter (yes) & 1.182 & 0.331 & $3.573^{* * *}$ \\
Parental beekeeping (yes) & 0.968 & 0.260 & $3.726^{* * *}$ \\
Livestock keeping (yes) & 1.165 & 0.277 & $4.213^{* * *}$ \\
\hline
\end{tabular}

703

${ }^{*}$ significance at $5 \%,{ }^{* *}$ significance at $1 \%,{ }^{* * *}$ significance at $0.1 \%$

704 
Appendix D. - Table of [1] correlation coefficients for possible continuous predictors (Pearson's r), [2] correlation coefficients for possible ordinal predictors (Spearman's rho), [3] variation of means of possible categorical predictors as well as [4] two-sample t-tests for possible dichotomous predictors of proportion of beekeeping dependence for subsistence and income (dependent variables; measured as $\%$ of the contribution of beekeeping to individual households' subsistence and income)

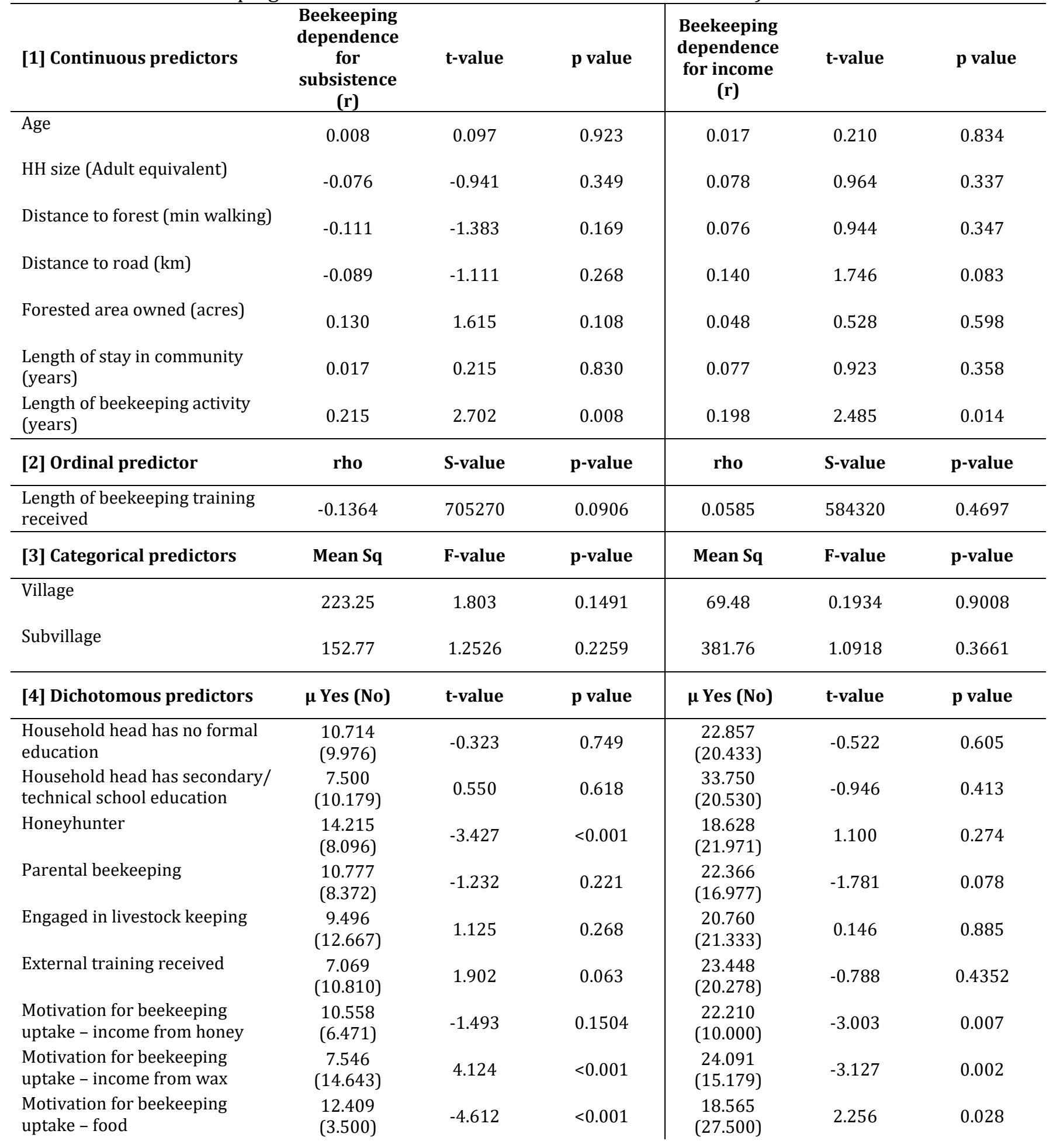




\begin{tabular}{|c|c|c|c|c|c|c|}
\hline $\begin{array}{l}\text { Motivation for beekeeping } \\
\text { uptake - like being in the forest }\end{array}$ & $\begin{array}{l}13.000 \\
(9.910)\end{array}$ & -0.983 & 0.3471 & $\begin{array}{l}18.000 \\
(21.069)\end{array}$ & 0.584 & 0.5711 \\
\hline $\begin{array}{l}\text { Motivation for beekeeping } \\
\text { uptake - medicine }\end{array}$ & $\begin{array}{l}16.706 \\
(6.875)\end{array}$ & -5.814 & $<0.001$ & $\begin{array}{c}16.471 \\
(23.029)\end{array}$ & 2.364 & 0.020 \\
\hline $\begin{array}{l}\text { Motivation for beekeeping } \\
\text { uptake - tradition }\end{array}$ & $\begin{array}{c}5.263 \\
(10.787)\end{array}$ & 1.814 & 0.0834 & $\begin{array}{c}23.684 \\
(20.478)\end{array}$ & -0.630 & 0.5351 \\
\hline $\begin{array}{l}\text { Beekeeping learned from - } \\
\text { family member }\end{array}$ & $\begin{array}{l}11.876 \\
(6.400)\end{array}$ & -3.131 & 0.002 & $\begin{array}{c}21.667 \\
(19.200)\end{array}$ & -0.767 & 0.445 \\
\hline $\begin{array}{l}\text { Beekeeping learned from - } \\
\text { village member }\end{array}$ & $\begin{array}{l}12.400 \\
(9.560)\end{array}$ & -1.415 & 0.163 & $\begin{array}{c}17.833 \\
(21.600)\end{array}$ & 1.088 & 0.2819 \\
\hline $\begin{array}{l}\text { Beekeeping learned from - self- } \\
\text { taught }\end{array}$ & $\begin{array}{c}4.211 \\
(10.939)\end{array}$ & 2.945 & 0.007 & $\begin{array}{c}18.684 \\
(21.177)\end{array}$ & 0.535 & 0.598 \\
\hline $\begin{array}{l}\text { Beekeeping learned from - } \\
\text { government training }\end{array}$ & $\begin{array}{c}3.000 \\
(10.600)\end{array}$ & 4.232 & $<0.001$ & $\begin{array}{c}17.500 \\
(21.104)\end{array}$ & 0.707 & 0.494 \\
\hline Member of beekeeping group & $\begin{array}{c}10.313 \\
(10.019)\end{array}$ & -0.149 & 0.882 & $\begin{array}{c}26.146 \\
(18.505)\end{array}$ & -2.412 & 0.018 \\
\hline
\end{tabular}


707 Appendix E. - Estimated parameters of binary logit and fractional components of a two-part 708 regression model for beekeeping dependence for subsistence

\begin{tabular}{lcccc}
\hline & $\begin{array}{c}\text { Binary } \\
\text { component } \\
\text { Estimate }\end{array}$ & SE & $\begin{array}{c}\text { Fractional } \\
\text { component } \\
\text { Estimate }\end{array}$ & SE \\
\hline Intercept & -0.45 & 0.849 & $-1.178^{* * *}$ & 0.343 \\
Length of beekeeping activity (years) & -0.001 & 0.019 & $0.013^{* *}$ & 0.004 \\
Honeyhunter (yes) & $1.647^{* *}$ & 0.605 & 0.034 & 0.111 \\
Motivation for beekeeping uptake - income from wax & $-2.705^{* * *}$ & 0.612 & -0.052 & 0.109 \\
Motivation for beekeeping uptake - food & $1.653^{*}$ & 0.732 & -0.582 & 0.303 \\
Motivation for beekeeping uptake - medicine & $3.642^{* * *}$ & 0.820 & -0.026 & 0.104 \\
Beekeeping learned from - self-taught & $-2.929^{* *}$ & 0.998 & 0.244 & 0.235 \\
Beekeeping learned from -government training & -1.491 & 0.974 & $-0.524^{* * *}$ & 0.081 \\
Forest area owned & 0.043 & 0.029 & 0.002 & 0.001 \\
\hline * significance at $5 \%{ }^{* *}$ significance at 1\%,***
\end{tabular}

${ }^{*}$ significance at $5 \%,{ }^{* *}$ significance at $1 \%,{ }^{* * *}$ significance at 0.1 
711 Appendix F. - Estimated parameters of binary logit and fractional components of a two-part

712 regression model for beekeeping dependence for income

\begin{tabular}{lcccc}
\hline & $\begin{array}{c}\text { Binary } \\
\text { component } \\
\text { Estimate }\end{array}$ & SE & $\begin{array}{c}\text { Fractional } \\
\text { component } \\
\text { Estimate }\end{array}$ & $\begin{array}{c}\text { SE } \\
\text { Intercept }\end{array}$ \\
Length of beekeeping activity (years) & -1.674 & 0.966 & $-1.264^{* * *}$ & 0.340 \\
Distance to forest (minutes walking) & 0.035 & 0.021 & $0.010^{*}$ & 0.005 \\
Distance to road (km) & $-0.012^{* *}$ & 0.004 & 0.001 & 0.001 \\
Forest area owned (acres) & 0.129 & 0.087 & $0.062^{*}$ & 0.026 \\
Parental beekeeping (yes) & 0.013 & 0.026 & -0.005 & 0.004 \\
External training received (yes) & 0.378 & 0.548 & 0.097 & 0.159 \\
Motivation for beekeeping uptake - income from honey & 0.027 & 1.020 & 0.013 & 0.283 \\
Motivation for beekeeping uptake - income from wax & $2.204^{* * *}$ & 0.677 & -0.001 & 0.302 \\
Motivation for beekeeping uptake - food & 0.918 & 0.504 & 0.183 & 0.159 \\
Motivation for beekeeping uptake - medicine & 0.281 & 0.668 & -0.288 & 0.223 \\
Motivation for beekeeping uptake - tradition & -0.277 & 0.573 & $-0.394^{*}$ & 0.163 \\
Beekeeping learned from -government training & -0.220 & 0.759 & -0.081 & 0.289 \\
Member of beekeeping group & -1.439 & 1.290 & -0.191 & 0.311 \\
\hline
\end{tabular}

* significance at $5 \%,{ }^{* *}$ significance at $1 \%,{ }^{* * *}$ significance at $0.1 \%$ 
Appendix G. - Table of [1] correlation coefficients (Pearson's r) for possible continuous predictors of beekeeping success measure (liters of honey harvested in the preceding 12 months) and [2] twosample t-test of mean values of beekeeping success measure for its possible dichotomous predictors

\begin{tabular}{|c|c|c|c|}
\hline [1] Continuous predictors & $\begin{array}{l}\text { Harvest quantities } \\
\text { (r) }\end{array}$ & t-value & p value \\
\hline Age & -0.139 & -1.620 & 0.108 \\
\hline Household size (Adult equivalent) & 0.019 & 0.220 & 0.826 \\
\hline Distance to forest (min walking) & 0.019 & 0.220 & 0.826 \\
\hline Distance to road $(\mathrm{km})$ & 0.191 & 2.261 & 0.025 \\
\hline Forested area owned (acres) & 0.187 & 2.216 & 0.371 \\
\hline Length of stay in community (years) & -0.046 & -0.537 & 0.593 \\
\hline Length of beekeeping activity & 0.078 & 0.897 & 0.371 \\
\hline Length of beekeeping training received & -0.059 & -0.686 & 0.494 \\
\hline [2] Dichotomous predictors $(y / n)$ & $\begin{array}{l}\text { Yes (mean liters } \\
\text { harvested) }\end{array}$ & $\begin{array}{c}\text { No (mean } \\
\text { liters } \\
\text { harvested) }\end{array}$ & p-value \\
\hline Household head has no formal education & 26.060 & 46.048 & 0.494 \\
\hline Household head has secondary and technical school & 29.179 & 26.667 & 0.902 \\
\hline Honeyhunter & 27.710 & 32.114 & 0.603 \\
\hline Parental beekeeping & 25.529 & 30.311 & 0.577 \\
\hline Engaged in livestock keeping & 11.960 & 32.955 & 0.002 \\
\hline External training received & 30.455 & 23.704 & 0.444 \\
\hline Motivation for beekeeping uptake - income from honey & 20.000 & 29.399 & 0.567 \\
\hline Motivation for beekeeping uptake - income from wax & 26.364 & 30.430 & 0.617 \\
\hline Motivation for beekeeping uptake - food & 19.462 & 32.969 & 0.082 \\
\hline Motivation for beekeeping uptake - like being in the forest & 29.648 & 21.667 & 0.342 \\
\hline Motivation for beekeeping uptake - medicine & 29.652 & 28.044 & 0.850 \\
\hline Motivation for beekeeping uptake - tradition & 30.636 & 19.737 & 0.157 \\
\hline Beekeeping learned from - family member & 19.325 & 33.165 & 0.083 \\
\hline Beekeeping learned from - village member & 30.523 & 23.679 & 0.399 \\
\hline Beekeeping learned from - self-taught & 29.355 & 26.923 & 0.792 \\
\hline Beekeeping learned from - government training & 30.612 & 5.125 & 0.001 \\
\hline Member of beekeeping group & 30.879 & 25.652 & 0.539 \\
\hline Received modern hives & 30.342 & 18.429 & 0.197 \\
\hline Requires training in modern hive construction & 32.475 & 26.590 & 0.596 \\
\hline Requires training in hive placement & 28.408 & 31.294 & 0.736 \\
\hline Requires training in capturing swarms & 30.461 & 26.646 & 0.659 \\
\hline Requires training in pest management & 22.443 & 36.105 & 0.175 \\
\hline Requires training in harvesting process & 28.434 & 29.560 & 0.926 \\
\hline Requires training in hive inspection & 28.496 & 32.083 & 0.695 \\
\hline Requires training in colony multiplication & 24.942 & 42.303 & 0.356 \\
\hline Does not require training & 30.574 & 5.750 & 0.002 \\
\hline Requires training in forage calendar & 32.772 & 18.889 & 0.063 \\
\hline
\end{tabular}




\begin{tabular}{llll} 
Requires training in feeding & 29.651 & 27.071 & 0.742 \\
Requires training in other processes & 31.370 & 23.054 & 0.291 \\
Received training in hive placement & 29.887 & 21.846 & 0.392 \\
Received training in harvesting process & 29.946 & 25.440 & 0.619 \\
Knowledge in marketing & 29.365 & 26.364 & 0.762 \\
Knowledge in local hive construction & 19.360 & 31.304 & 0.220 \\
Knowledge in hive placement & 14.353 & 31.217 & 0.032 \\
Knowledge in harvesting process & 22.429 & 30.844 & 0.286 \\
Knowledge in hive inspection & 26.320 & 36.703 & 0.529 \\
Knowledge in colony multiplication & 28.825 & 32.546 & 0.783 \\
Knowledge in feeding & 29.630 & 22.700 & 0.472 \\
Knowledge in pest control & 30.025 & 21.800 & 0.333 \\
Knowledge in capturing swarms & 30.439 & 22.609 & 0.307 \\
\hline
\end{tabular}


718 Appendix H. - Estimated parameters of binary logit and fractional components of a two-part 719 regression model for beekeeping success

\begin{tabular}{lcccc}
\hline & $\begin{array}{c}\text { Binary } \\
\text { component } \\
\text { Estimate }\end{array}$ & SE & $\begin{array}{c}\text { Fractional } \\
\text { component } \\
\text { Estimate }\end{array}$ & SE \\
\hline Intercept & -0.546 & 0.731 & $-3.715^{* * *}$ & 0.385 \\
Distance to road (km) & 0.189 & 0.146 & 0.049 & 0.042 \\
Forest area owned (acres) & 0.039 & 0.030 & $0.009 * *$ & 0.003 \\
Livestock keeping (yes) & 0.338 & 0.505 & $0.752^{* *}$ & 0.267 \\
Beekeeping learned from -government training & $-2.081^{*}$ & 1.035 & -0.445 & 0.397 \\
Does not require training & $-2.033^{*}$ & 0.966 & -0.762 & 0.554 \\
Knowledge in hive placement (yes) & -0.222 & 0.704 & 0.401 & 0.303 \\
Knowledge in local hive construction (yes) & 1.122 & 0.595 & 0.033 & 0.328 \\
External training received (yes) & 0.777 & 0.667 & 0.007 & 0.292 \\
Knowledge in colony multiplication (yes) & 1.465 & 1.073 & -0.462 & 0.310 \\
\hline
\end{tabular}




\begin{tabular}{|c|c|c|}
\hline Dependent variable & Statistical tests & Regression model \\
\hline $\begin{array}{l}\text { Beekeeping adoption (i.e. } \\
\text { beekeeper vs non-beekeeper) }\end{array}$ & $\begin{array}{l}\text { Two-sample t-test of the means for } \\
\text { possible continuous } \\
\text { Two-sample chi-squared test of the } \\
\text { means for possible dichotomous } \\
\text { predictors }\end{array}$ & Binary logit regression \\
\hline $\begin{array}{l}\text { Dependence on beekeeping for } \\
\text { subsistence (measured as \% of the } \\
\text { contribution of beekeeping to } \\
\text { individual households' subsistence) }\end{array}$ & $\begin{array}{l}\text { Pearson's r correlation coefficients } \\
\text { for possible continuous predictors } \\
\text { Spearman's rho correlation } \\
\text { coefficients for possible ordinal } \\
\text { predictors } \\
\text { Variation of means of possible } \\
\text { categorical predictors } \\
\text { Two-sample t-tests for possible } \\
\text { dichotomous predictors }\end{array}$ & Two-part fractional model \\
\hline $\begin{array}{l}\text { Dependence on beekeeping for } \\
\text { income (measured as \% of the } \\
\text { contribution of beekeeping to } \\
\text { individual households' income) }\end{array}$ & $\begin{array}{l}\text { Pearson's r correlation coefficients } \\
\text { for possible continuous predictors } \\
\text { Spearman's rho correlation } \\
\text { coefficients for possible ordinal } \\
\text { predictors } \\
\text { Variation of means of possible } \\
\text { categorical predictors } \\
\text { Two-sample t-tests for possible } \\
\text { dichotomous predictors }\end{array}$ & Two-part fractional model \\
\hline $\begin{array}{l}\text { Beekeeping success (measured as } \\
\text { liters of honey harvested in the } 12 \\
\text { months preceding the study) }\end{array}$ & $\begin{array}{l}\text { Pearson's r correlation coefficients } \\
\text { for possible continuous predictors } \\
\text { Two-sample t-test of the mean for } \\
\text { possible dichotomous predictors }\end{array}$ & Two-part fractional model \\
\hline
\end{tabular}




\section{References}

Abdulai, A., Huffman, W.E., 2005. The diffusion of new agricultural technologies: the case of crossbred-cow technology in Tanzania. American Journal of Agricultural Economics 87:3, 645-659.

Affognon, H.D., Kingori, W.S., Omondi, A.I., Diiro, M.G., Muriithi, B.W., Makau, S., Raina, S.K., 2015. Adoption of modern beekeeping and its impact on honey production in the former Mwingi District of Kenya: assessment using theory-based impact evaluation approach. International Journal of Tropical Insect Science 35, 96-102, 10.1017/S1742758415000156.

Aker, J.C., Mbiti, I.M., 2010. Mobile phones and economic development in Africa. The Journal of Economic Perspectives 24, 207-232.

Amulen, D.R., D’Haese, M., Ahikiriza, E., Agea, J.G., Jacobs, F.J., de Graaf, D.C., Smagghe, G., Cross, P., 2017. The buzz about bees and poverty alleviation: Identifying drivers and barriers of beekeeping in sub-Saharan Africa. PLoS one 12, e0172820.

Anand, S., Sisay, G., 2011. Engaging Smallholders in Value Chains: Creating new opportunities for beekeepers in Ethiopia. Oxfam Policy and Practice: Agriculture, Food and Land 11, 74-88.

Angelsen, A., Larsen, H.O., Lund, J.F., Smith-Hall, C., Wunder, S., 2011. Measuring livelihoods and environmental dependence: Methods for research and fieldwork. Earthscan Publications, Oxford, UK.

APFIC, 2010. Best practices to support and improve livelihoods of small-scale fisheries and aquaculture households, RAP Publication. FAO Regional Office for Asia and the Pacific, Bangkok, Thailand.

Blom, B., T. Sunderland \& D. Murdiyarso. 2010. Getting REDD to work locally: lessons learned from integrated conservation and development projects. Environmental Science \& Policy, 13, 164-172, 10.1016/j.envsci.2010.01.002.

Bradbear, N., 2018. The beekeeping sector needs realistic data. Bees for Development Journal, 128. ISSN 1477 - 6588, Monmouth, UK.

Bradbear, N., 2009. Bees and their role in forest livelihoods: a guide to the services provided by bees and the sustainable harvesting, processing and marketing of their products. Non-wood Forest Products 19, Food and Agriculture Organization of the United Nations, Rome, Italy. 
Bradbear, N., Fisher, E., Jackson, H., Bees for Development (Organization), 2002. Strengthening livelihoods : exploring the role of beekeeping development. Bees for Development, Monmouth, UK.

Brandon, K.E., Wells, M., 1992. Planning for people and parks: Design dilemmas. World Development 20, 557-570, 10.1016/0305-750X(92)90044-V.

Brooks, J. S., Franzen, M. A., Holmes, C. M., Grote, M., Borgerhoff Mulder, M., 2006. Testing hypotheses for the success of different conservation strategies. Conservion Biology 20, 1528-38, 10.1111/j.1523-1739.2006.00506.x.

Brown, J.C., 2001. Responding to deforestation: Productive conservation, the World Bank, and beekeeping in Rondonia, Brazil. Professional Geographer 53, 106-118, 10.1111/00330124.00273.

Brunette, W., Sudar, S., Borriello, G., 2014. Open data kit 2.0 tool suite. ACM, pp. 344-344.

Bryman, A., 2015. Social research methods. Oxford university press.

Campbell, B.M., 1996. The Miombo in transition: woodlands and welfare in Africa. CIFOR, CIFOR, Bogor, Indonesia.

Campbell, B.M., Angelsen, A., Cunningham, A., Katerere, Y., Sitoe, A., and Wunder, S., 2007. Miombo woodlands - opportunities and barriers to sustainable forest management. CIFOR, Bogor, Indonesia.

Carroll, T., Davey, C., Odera, F.O., 2017. Lessons from the field: Building from field experience to improve support for beekeeping in Kenya and Uganda - Project Report. African Beekeeping Resource Centre, Nakuru, Kenya.

Carroll, T., Kinsella, J., 2013. Livelihood improvement and smallholder beekeeping in Kenya: the unrealised potential. Development in Practice 23, 332-345, 10.1080/09614524.2013.781123.

Cohen, A., 2009. The Multidimensional Poverty Assessment Tool: Design, development and application of a new framework for measuring rural poverty. International Fund for Agricultural Development, Rome, Italy. 
820

821

822

823

824

825

826

827

828

829

830

831

832

833

834

835

836

837

838

839

840

841

842

Doss, C.R., Morris, M.L., 2001. How does gender affect the adoption of agricultural innovations?: The case of improved maize technology in Ghana. Agricultural Economics 25:1, 27-39, 10.1016/S0169-5150(00)00096-7.

Drescher, W., Crane, E., 1982. Technical cooperation activities: beekeeping: a directory and guide. Deutsche Gesellschaft fur Technische Zusammenarbeit (GTZ), Bonn, Germany.

Ellis, J., Ellis, A., 2008. African Honey Bee, Africanized Honey Bee, or Killer Bee, Apis mellifera scutellata Lepeletier (Hymenoptera: Apidae), Encyclopedia of Entomology. Springer, 59-66.

FAO, 2011. Beekeeping and sustainable livelihoods. UN Food and Agriculture Organization, Rome, Italy.

FAO, 2014. Capacity building in Community-based Forest Enterprise Development, UN Food and Agriculture Organization, Rome, Italy.

FAO, 2017. FAOSTAT Database. Food and Agriculture Organization of the United Nations, Rome, Italy.

Feder, G., Umali, D.L., 1993. The adoption of agricultural innovations: A review. Technological Forecasting and Social Change 43, 215-239, 10.1016/0040-1625(93)90053A.

Fisher, E., 1996. The social sustainability of beekeeping. Bees for Development Journal 39, 4-5, ISSN 1477-6588.

Fisher, E., 2000. Forest livelihoods: beekeeping as men's work in western Tanzania. In: Creighton, C. and Omari, C.K. (eds.) Gender, Family and Work in Tanzania. Ashgate, Aldershot, 138-176.

Fischer, E., Qaim, M., 2014. Smallholder farmers and collective action: what determines the intensity of participation? Journal of Agricultural Economics 65, 683-702, 10.1111/14779552.12060 .

Hausser, Y., Mpuya, P., 2004. Beekeeping in Tanzania: When the bees get out of the woods... An innovative cross-sectoral approach to Community-Based Natural Resource Management. Game \& Wildlife Science 21, 291-312. 
870

871

872

873

874

875

ICIPE, 2013. Linking insects to forest conservation through honey and silk. Department for International Development (DFID), London, UK.

IUCN. 2012. Motion 145. In World Conservation Congress, ed. I. U. f. t. C. o. Nature. Jeju, Korea: Union for the Conservation of Nature.

Ingram, V., Njikeu, J., 2011. Sweet, Sticky, and Sustainable Social Business. Ecology and Society 16, 37.

Jacobs, F.J., Simoens, C., Graaf, D., Deckers, J., 2006. Scope for non-wood forest products income generation from rehabilitation areas: focus on beekeeping. Journal of the Drylands 1, 171-185.

Jayne, T.S., Chamberlin, J., Headey, D.D., 2014. Land pressures, the evolution of farming systems, and development strategies in Africa: A synthesis. Food Policy 48, 1-17, 10.1016/j.foodpol.2014.05.014.

Kihwele, D.V.N., 1985. Constraints responsible for the low quality and quantity of honey and beeswax in Tanzania: A case study of Miombo woodlands. Proceedings of the Third International Conference on Apiculture in Tropical Climates, Nairobi, Kenya, 5-9 Nov 1984.

Lawton, R.M., 1982. Natural resources of miombo woodland and recent changes in agricultural and land-use practices. Forest Ecology and Management 4, 287-297, 10.1016/0378-1127(82)90006-8.

Markelova, H., Meinzen-Dick, R., Hellin, J., Dohrn, S., 2009. Collective action for smallholder market access. Food Policy 34, 1-7, 10.1016/j.foodpol.2008.10.001.

Mickels-Kokwe, G., 2006. Small-scale woodland-based enterprises with outstanding economic potential: the case of honey in Zambia. CIFOR, Bogor, Indonesia,

MNRT, 2016. Extension of Support for the National Forest and Beekeeping Programme (NFBKPII) Implementation - Project Completion Report. United Republic of Tanzania Ministry of Natural Resources and Tourism, Dar es Salaam, Tanzania.

Nel, E., Illgner, P., 2004. The contribution of bees to livelihoods in southern Africa. Fabricius, C., Koch, E., Magome, H. and S. Turner (eds): Rights, resources and rural development: community-based natural resource management in Southern Africa, 127134. 
Nel, E., Illgner, P.M., Wilkins, K., Robertson, M.P., 2000. Rural Self-Reliance in Bondolfi, Zimbabwe: the role of beekeeping. Geographical Journal 166, 26-34, 10.1111/j.14754959.2000.tb00004.x.

Okoye, C.U., Agwu, A.E., 2008. Factors Affecting Agroforestry Sustainability in Bee Endemic Parts of Southeastern Nigeria. Journal of Sustainable Forestry 26, 132-154, $10.1080 / 10549810701879685$.

Platteau, J.-P., 2004. Monitoring elite capture in community-driven development. Development and Change 35, 223-246, 10.1111/j.1467-7660.2004.00350.x

Rahm, M. R., Huffman, W. E., 1984. The adoption of reduced tillage: the role of human capital and other variables. American Journal of Agricultural Economics 66, 405-413, $10.2307 / 1240918$.

Ritchie, J., Lewis, J., Nicholls, C.M., Ormston, R., 2013. Qualitative research practice: A guide for social science students and researchers. Sage Publications, London, UK.

Roe, D., 2008. The origins and evolution of the conservation-poverty debate: a review of key literature, events and policy processes. Oryx 42, 491-503, $10.1017 /$ S0030605308002032.

Roe, D., Day, M., Booker, F., Zhou, W., Allebone-Webb, S., Kümpel, N., Hill, N.A.O., Wright, J., Rust, N., Sunderland, T.C.H., Redford, K., Petrokofsky, G., 2014. Are alternative livelihood projects effective at reducing local threats to specified elements of biodiversity and/or improving or maintaining the conservation status of those elements?: a systematic review protocol. Environ Evid 3, 1-8, 10.1186/2047-2382-3-6.

Roe, D., F. Booker, M. Day, W. Zhou, S. Allebone-Webb, N. A. O. Hill, N. Kumpel, G. Petrokofsky, K. Redford, D. Russell, G. Shepherd, J. Wright \& T. C. H. Sunderland, 2015. Are alternative livelihood projects effective at reducing local threats to specified elements of biodiversity and/or improving or maintaining the conservation status of those elements? Environmental Evidence, 4, 22, 10.1186/s13750-015-0048-1.

Saisana, M., Saltelli, A., 2010. The multidimensional poverty assessment tool (MPAT): Robustness issues and critical assessment. European Commission and Institute for the Protection and Security of the Citizen, Ispra, Italy. 
921 Salafsky, N., Wollenberg, E., 2000. Linking Livelihoods and Conservation: A Conceptual

922 Framework and Scale for Assessing the Integration of Human Needs and Biodiversity.

923 World Development 28, 1421-1438, 10.1016/S0305-750X(00)00031-0.

924

925

926

927

928

929

930

931

932

933

934

935

936

937

938

939

940

941

942

943

944

945

946

947

948

949

950

951

952

953

954

955

956

957

958

959
Shackleton, S., 2007. Background paper on small scale forest based enterprise development, Working Paper. CIFOR, Bogor, Indonesia.

Shiferaw, B., Hellin, J., Muricho, G., 2011. Improving market access and agricultural productivity growth in Africa: what role for producer organizations and collective action institutions? Food Security 3, 475-489.

SNV, 2016, Project assists beekeepers to develop resilience to resource scarcity, http://www.snv.org/update/project-assists-beekeepers-develop-resilience-resourcescarcity, accessed: $24^{\text {th }}$ July 2018.

Tesfaye, B., Begna, D., Eshetu, M., 2017. Beekeeping practices, trends and constraints in Bale, South-eastern Ethiopia. Journal of Agricultural Extension and Rural Development 9, 62-73, 10.4172/2332-2608.1000215.

UN General Assembly resolution 70/1, 2015. Transforming our world: the 2030 Agenda for Sustainable Development, $A / R E S / 70 / 1$. United Nations, New York, United States.

UNDP, 2013. Connecting poverty eradication and environmental sustainability is the 'make or break' for our future. United Nations Development Programme, New York, United States.

UNDP, 2015. Towards Green and Inclusive Prosperity. Building Green Economies that Deliver on Poverty Reduction. United Nations Development Programme, New York, United States.

UN-REDD. 2012. Forest management practices with potential for REDD+ in Zambia. Rome, Italy: UN-REDD Programme.

United Republic of Tanzania, 2002. The Beekeeping Act, in: Tourism, M.o.N.R.a. (Ed.). United Republic of Tanzania, Dar es Salaam, Tanzania.

United Republic of Tanzania. 2013. National Strategy for Reduced Emissions from Deforestation and Forest Degradation (REDD+). United Republic of Tanzania: Vice President's Office. 
962

963

965

966

967

968

969

970

971

972

973

974

975

976

977

978

USAID, 2012. The world market for honey - Capacity to improve agriculture and food security, in: CIAFS (Ed.), Market survey No. 1, Addis Ababa, Ethiopia.

USAID, 2014. USAID Biodiversity Policy, in: Development, U.S.A.I. (Ed.). United States Agency International Development, Washington D.C., United States.

USAID, 2015. Biodiversity and Development Handbook 2015, in: Development, U.S.A.I.

(Ed.). United States Agency International Development, Washington D.C., United States.

USAID, 2016, Promoting Agriculture, Health, and Alternative Livelihoods (PAHAL), USAID Nepal Fact Sheet. https://www.usaid.gov/nepal/fact-sheets/promoting-agriculture-healthand-alternative-livelihoods-pahal, Accessed: 24th July 2018.

World Bank, 2013, Forests and Poverty Reduction, Brief. The World Bank, Washington D.C., United States.

World Vision, 2015, Money from Honey, https://www.wvi.org/afghanistan/article/moneyhoney, Accessed: $24^{\text {th }}$ July 2018. 


\section{Acknowledgements}

980 The authors would like to acknowledge Saida Hussein, Jacqueline Kajembe and Juhudi

981 Mfaume for their efforts in survey administration and translation of interviews and focus

982 group discussions. The authors would like to thank Dr Remi d'Annunzio for his support

983 with the use of the statistics software R. We would also like to express our thanks to

984 Professor Dos Santos Silayo at the Faculty of Forestry and Nature Conservation of Sokoine

985 University of Agriculture, who facilitated administrative and logistical steps for the data

986 collection in the field. We would further like to thank the District governments of Manyoni,

987 Kondoa and Chemba for allowing us to collect data in the study communities. We sincerely

988 thank the three anonymous reviewers whose suggestions helped to improve and clarify

989 this manuscript. Lastly, we would like to extend our gratitude towards the men and women

990 of Msemembo, Sasilo, Kwa Mtoro and Paranga for their warm welcome and generosity. 